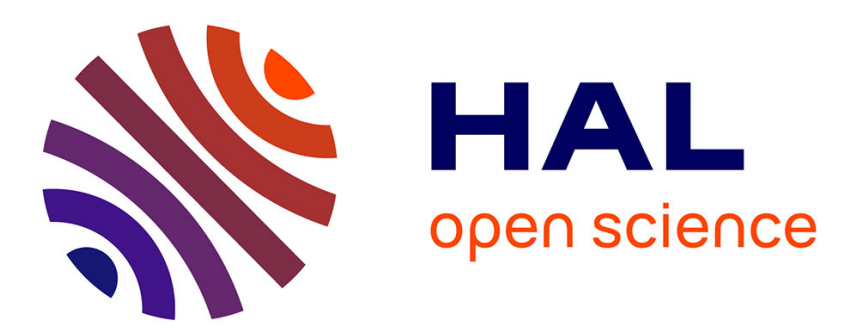

\title{
Comparison of the behaviour of various geotextiles used in the filtration of clayey sludge: An experimental study
}

G. Stoltz, Philippe Delmas, C. Barral

\section{To cite this version:}

G. Stoltz, Philippe Delmas, C. Barral. Comparison of the behaviour of various geotextiles used in the filtration of clayey sludge: An experimental study. Geotextiles and Geomembranes, 2019, 47 (2), pp.230-242. 10.1016/j.geotexmem.2018.12.008 . hal-02608533

\section{HAL Id: hal-02608533 \\ https://hal.inrae.fr/hal-02608533}

Submitted on 16 May 2020

HAL is a multi-disciplinary open access archive for the deposit and dissemination of scientific research documents, whether they are published or not. The documents may come from teaching and research institutions in France or abroad, or from public or private research centers.
L'archive ouverte pluridisciplinaire HAL, est destinée au dépôt et à la diffusion de documents scientifiques de niveau recherche, publiés ou non, émanant des établissements d'enseignement et de recherche français ou étrangers, des laboratoires publics ou privés. 


\section{Comparison of the behaviour of various geotextiles used in the filtration of clayey sludge: An experimental study}

Guillaume Stoltz ${ }^{1(*)}$, Philippe Delmas ${ }^{2}$, Camille Barral ${ }^{3}$

${ }^{1}$ Irstea-RECOVER Unit, 3275 Route Cézanne,13182 Aix-en-Provence Cedex 5, France, Email: guillaume.stoltz@irstea.fr,Phone number:+33442666964

${ }^{2}$ Full Professor of the Chair of Geotechnics, Cnam, EPN 1, Construction-Géotechnique, rue Conté 2, 75141 Paris cedex 03, France, Email: philippe.delmas@lecnam.net, Phone number: +33140272878, ${ }^{3}$ Lecturer, Ecole SITI, Département ICENER, Construction-Géotechnique, rue Conté 2, 75141 Paris cedex 03, France, Email: camille.barral@cnam.fr ,Phone number: +33140272878,

(*) Corresponding author : Prof. Philippe Delmas, Cnam, EPN 1, Construction-Géotechnique, rue Conté 2, 75141 Paris cedex 03, France, Email: philippe.delmas@lecnam.fr Telephone: $+33140272878$

\section{Abstract}

This paper presents the results of an experimental study of various geotextiles used to filter clayey sludge. The use of geotextiles to filter clayey sludge or suspensions of fine particles in water is more complex than that for filtering suspensions of granular soils. In practice, such applications generally use flocculants to postpone the formation of a low-permeability filter cake. The objective of the present study, which does not use flocculants, is to determine how geotextile characteristics affect the capacity of the geotextile to filter clayey sludge. Three key questions are addressed: (1) What are the main differences between vertical and horizontal filtration? (2) How do geotextile characteristics (nature, opening size, permeability, etc.) affect its capacity to filter clayey sludge? (3) How do clayey sludge characteristics (i.e., grain size distribution and concentration) and the type of flow (i.e., constant head or constant flow) affect the filtering capacity of geotextiles? To evaluate the capacity of a geotextile to filter clayey sludge, we propose three relevant criteria and analyse two filtration phases induced by different cake-formation processes (controlled by the geotextile and controlled by the filter cake). To 
determine the main differences between vertical and horizontal filtration, the settling of fines in the testing device and its influence on the results are analysed and discussed. This study shows that, for the various clayey sludge tested, the geotextiles (needle-punched nonwoven and thermally bonded nonwoven) with the smallest opening sizes $\left(\mathrm{O}_{90} \leq 60 \mu \mathrm{m}\right)$ give the most promising results for filtering fines without the use of flocculants. Of these geotextiles, the thermally bonded nonwoven structure seems to offer the best filtration performance for the largest range of fines concentration in the sludge.

Keywords:

Geosynthetics, geotextiles, filtration, clayey sludge, fines, suspension.

\section{INTRODUCTION}

In many filtering applications such as in drainage systems, geosynthetics are in contact with the upstream soil, which may include fine particles. In typical applications of this type, the geotextile is confined between the upstream soil and the drainage layer and it helps to create an equilibrium with the upstream particles after limited washout of finer particles by inducing a self-filtration zone (bridging) at the interface between the geotextile and the upstream soil. In this case, the geotextile design is based on three criteria: (i) the geotextile must retain the largest particles and stabilise the skeleton, (ii) it must let the finer particles pass, and (iii) it must maintain a minimum permeability normal to the plane. In addition, some authors such as Giroud (1982), Bouthot et al. (2002) and Aydilek et al. (2005) consider that the number of constrictions of the geotextile influences its filtration behaviour.

Also in some filtration applications, geotextiles may also be placed unconfined with the upstream soil or in contact with soft, fine, saturated soils. In these cases, provided the soil is unconsolidated, the water flow may erode the soil and become charged with fines. With so 
many small particles in suspension, the geotextile filter cannot create the self-filtration zone described above. In the case of geotextiles with large opening sizes, the geotextile will let many fine particles pass into the drainage system, which in most cases resulting in clogging of the drainage system. The fine particles progressively accumulate at the surface and inside the geotextile, which leads to an increase in the water-head loss at the level of the geotextile by reducing the water flow through the geotextile. This process reduces the water velocity of the corresponding erosion and, consequently, of the number of fine particles in suspension that reach the geotextile. Understanding the process of fine-particle retention by a geotextile and predicting the critical water-head loss in the geotextile is thus of great interest. This phenomenon has been studied by several researchers such as Le Coq (1996), who proposed a model to describe the increase in head loss through a filter due to clogging and Faure et al. (2006), who proposed a method to predict geotextile clogging during filtration of suspended solids. This last study focuses on clay suspensions with very low concentrations (inferior to one gram per litre) and is extended by a very recent study conducted by Sabiri et al. (2017).

The capacity of geotextiles to filter fine particles in suspension is also exploited by environmental applications to dewater sludge. In this case, the sludge is typically introduced inside a geotextile tube or a container, which retains the solid fraction of the sludge and lets most of the liquid effluent pass through (Yee et al., 2012). Flocculants are generally necessary to postpone or avoid the formation of a low-permeability filter cake at the surface of the geotextile and to maintain the proper filling of the container by solid particles (Moo-Young et al. 2002; Muthukumaran and Ilamparuthi, 2006; Lawson, 2006; Delmas, 2007; Satyamurthy and Bhatia, 2009).

More rarely, in the case of draining mining sludge, geotextile filtration of fine particles in suspension without flocculants has also been studied. Recently, studies of filtering fine-grained mineral sludge confirm the feasibility of geotextile filtration for dewatering high-clay-content 
materials with low hydraulic conductivity (Bourgès-Gastaud et al., 2014). A major difference exists between (1) classical geotextile filtration of compacted soil and (2) geotextile filtration of clayey sludge. In the former case, exogenous water is drained, and the volume is theoretically infinite. In this case, the geotextile must remain permeable during the service life of the earthwork or structure, and clogging, which corresponds to a significant decrease in permeability (Veylon et al. 2016), must be avoided. In the latter case, endogenous water is drained, and the volume is theoretically finite. Filtering such material induces a significant decrease in the permeability of the cake-geotextile system due to the accumulation of fine particles. This phenomenon, which could be considered as clogging, may not be a problem if the entire endogenous volume of water is drained. In this case, it is more appropriate to talk about filter-cake initiation instead of clogging.

All the recent studies concerning clayey-sludge filtration confirm that the physics of filtering particles in suspension with a geotextile differs from the physics of filtering fine, confined soils. These studies show that the geotextile exerts an influence mainly at the early stage before the creation of the filter cake (Kutay and Aydilek, 2004; Weggel and Dortch, 2012). After that stage, the filter cake becomes the major contributor to the permeability of the clayey sludge/filter cake/geotextile system. At the onset of filtration, when the geotextile is clean, sludge filtration is governed by the properties of the geotextile. Over time, as the filtration proceeds, a layer of solids (filter cake) is expected to deposit on the surface of the geotextile. The extent of filter-cake formation and its stability depend on the particle size and particle-size distribution of the solids in the sludge, the concentration of particles, the flow rate, the pressure difference upstream and downstream of the geotextile and the structure of the geotextile (SooKhean Teoh et al., 2006; Chi Tien et al., 2011; Weggel and Ward, 2012).

Most studies that use clayey sludge filtration tests to assess geotextile filtration performance use a vertical cell in which the filter geotextile is positioned horizontally (Moo-Young et al., 
107 Ilamparuthi, 2006; Weggel and Dortch, 2012; Bourgès-Gastaud et al., 2014; Sabiri et al., 2017).

108 However, to better simulate filtration that occurs on the sides of a geotextile dewatering tube

109 (Yee et al., 2012) or upstream of a vertical drainage trench (Veylon et al., 2016), it is more

110 relevant to position the filtration cell horizontally, which orients the filter geotextile vertically.

111 In this situation, the formation of the filter cake can be affected by sedimentation of particles

112 that can settle before reaching the filter geotextile (where they settle depends on the particle

113 size and particle-size distribution in the solids in the sludge, the particle concentration particles,

114 and the flow rate). Generally, hanging bag tests are used to assess the dewatering performance

115 of the geotextile tube (Kutay and Aydilek, 2004; Koerner and Koerner, 2006; Weggel et al.,

116 2011). However, in such hanging bag tests, clayey sludge is poured into the bags without added

117 pressure, which is not fully representative of the filling of dewatering tubes in the field, in which

118 the sludge is under pressure.

119 When the filter cake forms, the filtration will generally become controlled after a short period,

120 not by the properties of the geotextile but by the properties of the filter cake. In this case, the

121 filtration process can be evaluated by the theory of filtration in porous media. One main

122 governing parameter will be the increased loss of liquid head through the filter cake as the cake

123 thickness increases during liquid flow. This increase in head loss is partly due to the increased

124 length of the channels through which the water passes.

125 Another important parameter is the retention, or removal efficiency, of particles from the 126 sludge. In addition, this parameter may, after a relatively short period of time, be determined 127 more by the properties of the filter cake than by the properties of the geotextile. Nevertheless, 128 geotextile characteristics remain important in determining the creation of the cake and its 129 characteristics and stability. Aydilek and Edil (2003) studied the long-term filtration of 
nonwoven geotextile-sludge systems and emphasised the role of geotextile permittivity (i.e.,

131 permeability normal to the plane divided by the geotextile thickness).

132 To summarise, the global parameters governing filtration performance include but are not

133 limited to the particle type, concentration, size distribution, type of water flow, geotextile

134 characteristics (e.g., opening size, permeability normal to the plane, structure of the geotextile),

135 and orientation of the filter geotextile (i.e. horizontal or vertical).

136 In general, three overall performance criteria should be considered when using geotextiles to

137 filter suspensions of solids without flocculants:

138 - The first criterion concerns the retention capacity of the filter: over a relatively short time

139 period, the solid concentration upstream of the geotextile will increase significantly.

140 - The second criterion is linked to the inevitability of some of the finest particles passing

141 through the geotextile because the geotextile opening size cannot be smaller than the 142 smallest particles. This criterion is reasonably satisfied if the initial loss of solids through

143 the geotextile is limited and stops, or is at least significantly reduced, relatively soon after 144 the onset of filtration.

145 - The third criterion is linked to characteristics of the filter cake that, once formed, must 146 remain as permeable as possible.

147 Following the first two criteria, we can deduce that the effluent quality must be acceptable with 148 respect to environmental impact and preferably remain constant with time.

149 Considering the present knowledge of geotextile filtration of fines in suspension without using 150 additives, it seems important to understand more precisely how the most important geotextile 151 characteristics affect (i) the formation of filter cake from various clayey sludge and (ii) the 152 evolution of the "cake-geotextile" filtration system. Therefore, we use a systematic parametric 153 approach, in which we first evaluate how the filtration system is influenced by several key 154 parameters, including (a) the type of soil (e.g., well graded or uniform), (b) the concentration 
155 of fine particles, (c) the type of water flow (e.g., constant flow or constant head) and (d) the

156 type of geotextile. To be representative of the filtration that occurs on the sides of a geotextile

157 dewatering tube or on the side of a vertical drainage trench, and thus separate filtration from

158 sedimentation phenomenon, the filter geotextile is positioned vertically in the filtration cell. We

159 discuss how these experimental conditions affect the experimental results.

160 After a short description of the main phenomena involved in the geotextile filtration of fine

161 particles in suspension, we describe the performance of various geotextile filters and compare

162 their performance based on an analysis of (i) the retained soils and passed soils before and after

163 the formation of the filter cake, and (ii) the characteristics of the filter cake.

\section{Phenomena INVOlVed In The FiLTRATION OF FINE PARTICLES IN SUSPENSION}

165 For geotextile filtration of fine particles in suspension, three main phenomena can be observed:

166 (1) a filtration controlled by the geotextile until the eventual creation of a filter cake, which may

167 be considered as a clog in the system from the point of view of geotextile filtration; (2) a

168 filtration controlled by the formation of the filter cake; and (3) the particles settle inside the 169 sludge, which causes variations in sludge concentration; this last phenomenon indirectly 170 interacts with the filtration processes defined above.

\subsection{FILTRATION CONTROLLED BY GEOTEXTILES}

172 In this case, particle retention is determined by the geotextile properties, and clogging is

173 considered from the point of view of geotextile filtration. Clogging corresponds to the end of

174 the passage of fine particles by the geotextile. Once clogging occurs, the filtration is governed

175 by the filter cake that has formed in contact with the geotextile. Before the formation of the 176 filter cake, geotextile filtration may be described by the following analysis. 
177 Considering a given concentration $C_{\mathrm{s}}\left(\mathrm{kg} / \mathrm{m}^{3}\right.$ or $\mathrm{g} / \mathrm{L}$ in this study) of solid fines and a given flow

$178 F_{\mathrm{w}}\left(\mathrm{m}^{3} / \mathrm{s}\right.$ or $\mathrm{L} / \mathrm{min}$ in this study) of sludge, the theoretical flux $Q_{\mathrm{s}}(\mathrm{kg} / \mathrm{s})$ (with no filtration) of 179 solid particles passing through the geotextile per second is

$$
Q_{\mathrm{s}}=F_{\mathrm{w}} C_{\mathrm{s}}
$$

182

183 For a given geotextile with a filtration property A, the total mass $m_{\mathrm{pA}}(\mathrm{kg})$ of particles passing through geotextile A prior to cake formation is

$$
m_{\mathrm{pA}}=Q_{\mathrm{s}} t_{\mathrm{A}}-m_{\mathrm{rA}}
$$

where $t_{\mathrm{A}}(\mathrm{s})$ is the time interval between the onset of filtration and cake formation and $m_{\mathrm{rA}}(\mathrm{g})$

188 is the mass of the retained particles.

190 Similarly, with a more open geotextile, corresponding to filtration property $\mathrm{B}$, we have $t_{\mathrm{B}}>t_{\mathrm{A}}$,

191 and the mass $m_{\mathrm{rB}}$ of the retained particles and the corresponding mass $m_{\mathrm{pB}}$ of the particles

192 passing through geotextile B can be defined. Repeating this reasoning for a geotextile with a

193 filtration property $\mathrm{C}$, we have $t_{\mathrm{C}}>t_{\mathrm{B}}$, the mass of the retained particles is $m_{\mathrm{rC}}$, and the 194 corresponding mass of the particles passing through geotextile $\mathrm{C}$ is $m_{\mathrm{pC}}$. Figure 1 shows the 195 evolution of the filtration phenomena for the three geotextiles with different filtration properties 196 (A, B, C). Figure 1(a) shows the pressure drop versus time until cake formation for the three

197 geotextiles. Cake formation may be characterised by a given overpressure ( $\left.\Delta p_{\text {cf }}\right)$ upstream of 198 the geotextile. Figure 1(b) shows the mass of particles that passes through each individual 199 geotextile versus the theoretical imposed flow of particles.

200 From this figure, we can deduce the following: 
- If the geotextile has small opening size (case A), the filter cake forms rapidly (very few fines pass through the geotextile) and practically no fines pass through the geotextile during the filter-cake phase.

- When the geotextile opening size increases (case B), more fines pass through the geotextile prior to cake formation, and some fines pass through during the filter-cake phase.

- For large geotextile opening size (case C), even more fines pass through the geotextile before cake formation, and a significant mass of fines passes through during the filter-cake phase (i.e., unstable cake).

\subsection{FILTRATION CONTROLLED BY THE FORMATION OF A FILTER CAKE}

210 The geotextile filtration process described in section 2.1 may lead to the deposition of a filter

211 cake on the upstream side of the geotextile, resulting in a filtration process determined by the 212 build-up of head-loss drop across the filter cake (Figure 1), which induces a pressure drop in 213 the sludge. To model this pressure drop, we use an equation developed to model the solid-liquid 214 separation process (Kozeny, 1927). By assuming an incompressible filter cake, the pressure 215 drop may be estimated by

$$
\frac{\mathrm{d} V}{\mathrm{~d} t}=\frac{\Delta p_{\mathrm{f}} A}{\mu\left(\frac{\alpha C_{\mathrm{S}} V}{A}+R_{\mathrm{m}}\right)}
$$

218 where $A$ is the effective filtration area $\left(\mathrm{m}^{2}\right), V$ is the volume of filtrate $\left(\mathrm{m}^{3}\right), t$ is the filtration 219 time (s), $\Delta p_{\mathrm{f}}$ is the pressure drop through the filter cake $(\mathrm{Pa}), \alpha$ is the specific filter-cake resistance $(\mathrm{m} / \mathrm{kg}), R_{\mathrm{m}}$ is the filter-medium resistance $\left(\mathrm{m}^{-1}\right), C_{\mathrm{s}}$ is the sludge concentration $\left(\mathrm{kg} / \mathrm{m}^{3}\right)$ and $\mu$ is the viscosity of the liquid phase of the suspension $\left(\mathrm{N} \mathrm{s} / \mathrm{m}^{2}\right)$. Integrating the 222 differential equation leads to 


$$
\frac{t}{V}=\alpha\left(\frac{\mu C_{\mathrm{s}}}{2 A^{2} \Delta p_{\mathrm{f}}}\right) V+R_{\mathrm{m}}\left(\frac{\mu}{A \Delta p_{\mathrm{f}}}\right)
$$

225 Graphing the experimental data in the form of $t / V$ versus $V$ allows us to determine the specific 226 filter-cake resistance $\alpha$ and the filter medium resistance $R_{\mathrm{m}}$ and to roughly verify the assumption 227 that the filter cake is incompressible. Equation (4) uses $t / V$, which gives the inverse of the 228 average filtration rate over the period measured and through the surface area of the filter in the test. Knowledge of $t / V$ facilitates the evaluation of the filtration rate over time, which is useful 230 for assessing large-scale applications.

\subsection{SETTLING OF PARTICLES INSIDE THE SLUDGE}

232 For a vertical filter geotextile, the settling of particles in the sludge on the upstream side of the geotextile may affect the concentration of solid fines and size distribution that contact the geotextile. This phenomenon depends on the particle diameters, the initial particle concentrations and/or the test conditions (flow rate and length of the filtration cell principally). In addition, the settling properties of the fine solids that pass through the filter geotextile will determine the area affected by the spreading of the particles downstream. The settling of particles in suspension in a liquid depends on the properties of the particles (shape, size, specific weight, concentration) and of the liquid (density, viscosity, temperature).

240 A settling particle reaches its terminal velocity when the magnitude of the gravitational force 241 equals the magnitude of the drag force. The terminal velocity depends on fluid density, the 242 projected area of the particle on a plane normal to the settling direction and a drag factor. The 243 drag factor depends, among other parameters, on the shape factor, which provides a measure of 244 the deviation from a spherical shape (a unity shape factor corresponds to a perfect sphere). 245 Assuming spherical particles, the terminal velocity for fine particles settling in water may be 246 estimated by using Stokes law, which is valid for a Reynolds number between $10^{-5}$ and 2: 


$$
V_{\mathrm{t}}=D_{\mathrm{h}}^{2} \mathrm{~g}\left(\rho_{\mathrm{p}}-\rho_{\mathrm{w}}\right) / 18 \mu
$$

248 In Equation (5), $V_{\mathrm{t}}$ is the terminal velocity of the settling particles $(\mathrm{m} / \mathrm{s}), D_{\mathrm{h}}$ is the hydraulic 249 diameter of the particles $(\mathrm{m}), g$ is the acceleration due to gravity $\left(\mathrm{m} / \mathrm{s}^{2}\right), \rho_{\mathrm{p}}$ is the particle density $250\left(\mathrm{~kg} / \mathrm{m}^{3}\right), \rho_{\mathrm{w}}$ is the density of water $\left(\mathrm{kg} / \mathrm{m}^{3}\right)$ and $\mu$ is the viscosity of the liquid $\left(\mathrm{N} \mathrm{s} / \mathrm{m}^{2}\right)$.

251 Equation (5) assumes that particles settle without any interference from other particles (discrete 252 settling). Given high particle concentrations (greater than $0.1 \%$ by volume), the settling velocity 253 is reduced compared with the velocity for discrete settling because of the increase in apparent 254 viscosity and fluid density (hindered settling). The hindered-settling velocity may be estimated 255 from the terminal settling velocity by applying a correction factor:

$$
V_{\mathrm{h}}=\varepsilon^{n} V_{\mathrm{t}}
$$

where $V_{\mathrm{h}}$ is the hindered-settling velocity of the particles $(\mathrm{m} / \mathrm{s}), V_{\mathrm{t}}$ is the terminal settling velocity of the particles $(\mathrm{m} / \mathrm{s}), \varepsilon$ is the ratio of liquid volume to sludge volume and $n$ is a dimensionless exponent $(n=3.65$ for $\varepsilon>0.6)$ (Lydersen, 1979).

\section{DESCRIPTION OF THE EXPERIMENTAL STUDY}

262 The experiment was designed to facilitate the systematic study of how geotextile characteristics 263 affect the formation of the filter cake. The key parameters governing such filtration systems 264 include but are not limited to the type of water flow, the particle-size distribution, the particle 265 concentration and the geotextile characteristics (e.g., opening size, permeability normal to the 266 plane, and dimensional structure). The various parameters of the testing procedure and the corresponding assumptions are presented below. 


\subsection{ASSUMPTIONS, TEST PARAMETERS AND TEST CONDITIONS}

\subsubsection{TYPE OF SOILS USED FOR THE FILTRATION TESTS}

270 The type of the soil in suspension is expected to strongly influence the filtration behaviour. The 271 soil may be described by several parameters such as particle-size distribution, particle type, 272 particle shape and/or particle clay content and plasticity index. As a first step, to reduce the 273 number of tests, we check only how the shape of the granularity curve affects filtration for two 274 soil types: uniform and well-graded. A kaolinite and a silt soil are combined to create the two 275 soils used in these tests.

Figure 2 and Table 1 present the particle-size distributions of the two soils used in these tests. Soil $\mathrm{A}$ is a kaolinite with a uniform granularity $(\mathrm{CU}=4.5)$ and soil $\mathrm{B}$, which is the combination of kaolinite and silt $(\mathrm{CU}=13)$, is a fine, well-graded soil.

\subsubsection{Sludge PROPERTIES, CONCENTRATION OF PARTICles AND FlOW} CONDITIONS

The two soils were tested at different particle concentrations and flow conditions. For the lowest concentrations, a constant sludge flow was used. A flow of $0.5 \mathrm{~L} / \mathrm{min}$ was maintained until a pressure of $40 \mathrm{kPa}$ was attained on the upstream side of the geotextile filter, following which the test continued with a constant head. For the highest concentrations, a constant head (with a maximum of $10 \mathrm{kPa}$ ) was used. The flow rate of $0.5 \mathrm{~L} / \mathrm{min}$ was chosen to adapt to the cell dimensions and to the range of solid concentrations (70 to $300 \mathrm{~g} / \mathrm{L}$ ) and to well separate filtration and sedimentation behaviour inside the cell. In the two studies that involved filtration tests at constant flow, Faure et al. (2006) applied in their study a flow rate of around $5 \mathrm{~L} / \mathrm{min}$ for sludge with solid concentration from 0.1 to $1 \mathrm{~g} / \mathrm{L}$ and Sabiri et al. (2017) applied in their 
study a flow rate from 0.14 to $0.5 \mathrm{~L} / \mathrm{min}$ for sludge with solid concentration of $1 \mathrm{~g} / \mathrm{L}$. Thus, the flow rate of $0.5 \mathrm{~L} / \mathrm{min}$ is the same order of magnitude as obtained in previous laboratory studies but is less than the real flow rate used to fill a dewatering tube (Yee et al., 2012). Table 2 presents the different conditions under which the tests were done.

\subsubsection{TESTING DEVICE AND SETUP OF APPARATUS}

Figure 3 and Figure 4 present the test cell used to filter the sludge. A tank upstream with a stirring tool maintained a constant and uniform predefined concentration of fines in the incoming sludge. The monitored pumping system controlled the flow conditions at the entrance

of the filtration cell. A pressure sensor was fixed at the top of the cell. The 150-mm-diameter filtration geotextile was held by a metallic grid to avoid deformation of the geotextile during the test. The sludge that passed through the geotextile was regularly weighed during the filtration test and collected for further analysis.

Note that the cell (volume $8.8 \times 10^{-3} \mathrm{~m}^{3}$ ) was oriented horizontally and the filtration geotextile vertically. In this configuration, the settling and sedimentation behaviour is separated from the filtration behaviour.

\subsection{GEOTEXTILES TESTED AND CORRESPONDING TEST CONDITIONS}

Table 3 and Table 4 summarise the characteristics of the various geotextiles tested and the corresponding configuration of the tests. To evaluate the influence of different structures with similar characteristic opening sizes, we tested a metallic sieve $\left(\mathrm{W}-2 ; \mathrm{O}_{90}=63 \mu \mathrm{m}\right.$; identified by an asterisk in Table 3) to simulate a woven geotextile with a characteristic opening size close to $50-60 \mu \mathrm{m}$. This approach was used because of the difficulty of finding a woven geotextile with such a small opening size. 


\section{EXPERIMENTAL RESULTS OF THE FILTRATION STUDY}

316 A first set of tests of the various geotextiles was done under constant-flow and constant-head 317 conditions and with different concentrations of soils and fines. These tests were stopped when 318 visual inspection indicated that fines had ceased to pass. This approach allowed us to study how 319 the geotextile determines the filtration (section 2.1). To specify the filtration characteristics 320 when determined by the filter cake and for constant-head conditions (section 2.2), some tests 321 were repeated with a longer duration (up to 90 minutes).

\subsection{OBSERVATIONS AND PARAMETERS MONITORED TO CHARACTERISE} GEOTEXTILE-CONTROLLED FILTRATION

The first set of tests allows us to determine and compare the characteristics of filtration when it is controlled by the geotextile. Therefore, detailed observations and specific parameters linked to this specific phase of the filtration system were followed and analysed.

\subsubsection{OBSERVATIONS OF DIFFERING FILTRATION BEHAVIOURS}

Depending on the type of geotextile, the concentration and the hydraulic conditions, different

329 filtration behaviours occur:

330 - When a large quantity of sludge passes through the geotextile, the cell cannot be filled, and $331 \quad$ stable filtration is not established.

332 - When a limited quantity of sludge passes through the geotextile, the cell fills, and one of the 333 two following stable systems is established:

334 - the geotextile is almost completely clogged after a certain period; no fines but also nearly no water passes through the geotextile by the end of the test; 
- a stable filtration system is established; after a certain period, water still passes through the system, and either a relatively small flux of fines passes through or some fines continue to pass through.

339 For the lowest concentrations of fines and for constant flow, Table 5 presents the ratio of the

340 cumulative mass of the sludge flow through the geotextile to the theoretical cumulative mass

341 of the sludge flow through the geotextile. The abbreviation "cnf" (for "cell not filled") indicates

342 that the cell was not filled after the test, and the abbreviation "cfnst" indicates that the cell was

343 filled but the filter was not stable. In a large majority of the cases, the cell cannot be filled,

344 which means that the geotextile opening sizes are too large to create a filter and/or that the

345 concentration of fines in the sludge is too low.

346 Similarly, for the highest concentrations of fines and for constant-head conditions, part 1 of

347 Table 6 indicates whether the systems were stable, as determined based on the evolution of

348 the mass of the sludge that passes through the filter and/or the mass of fines that passes 


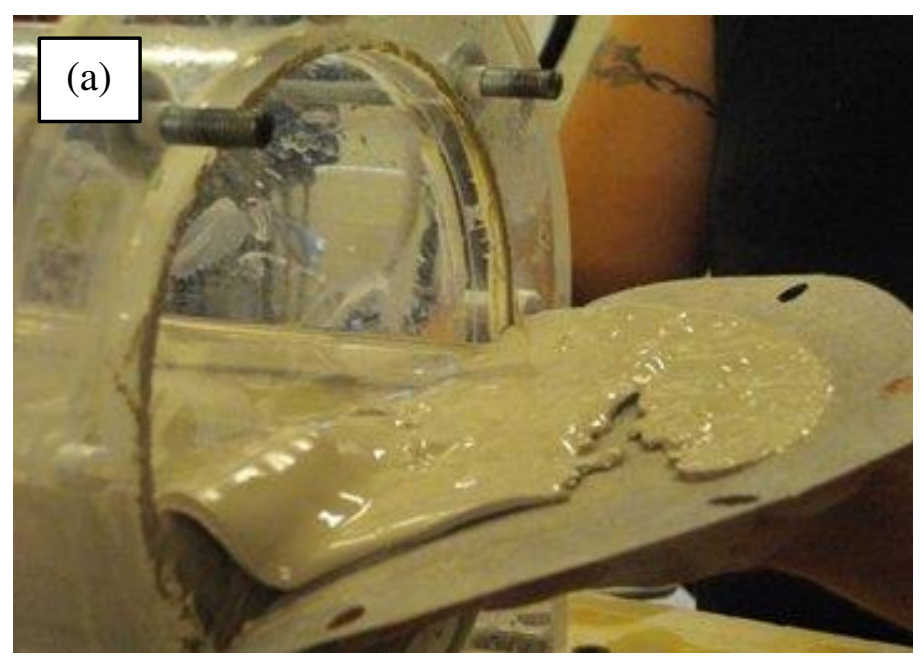

349 through the filter.

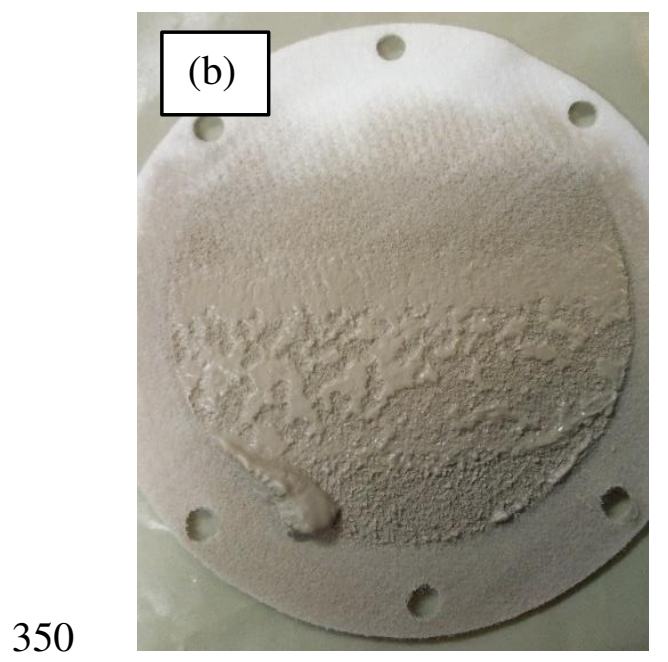


351 Figure 5 (a) shows a view of typical filtration cell at end of test (NWTB-1, constant flow

352 condition, soil $\mathrm{A}$ at $200 \mathrm{~g} / \mathrm{L})$ and

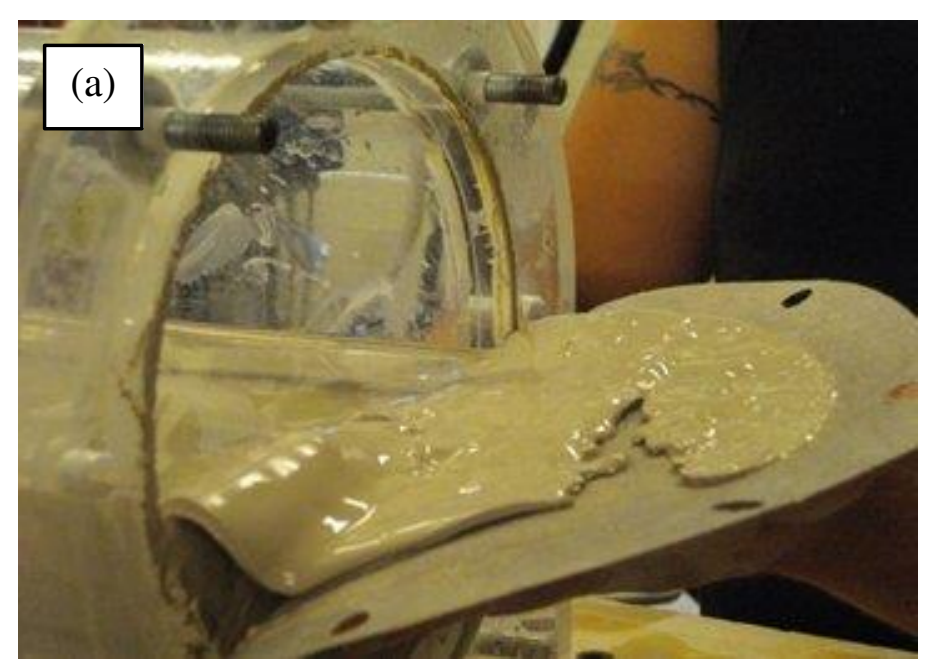

353

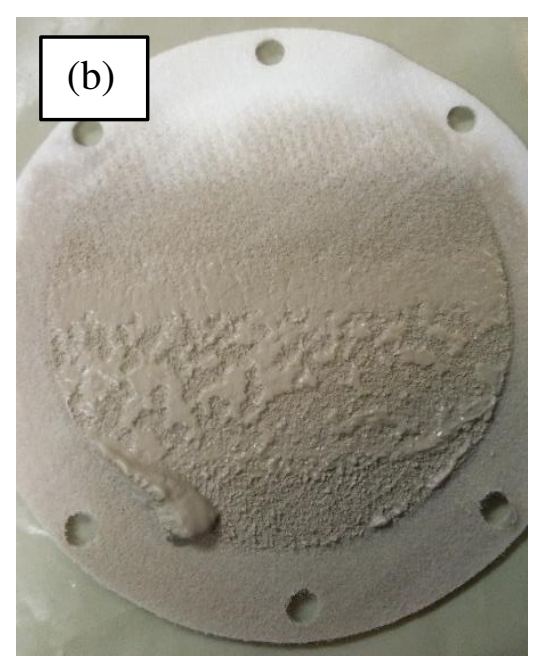


Figure 5 (b) shows a view of a filter geotextile at end of test (NWMB-2, constant flow condition,

355 soil $\mathrm{B}$ at $200 \mathrm{~g} / \mathrm{L})$. From
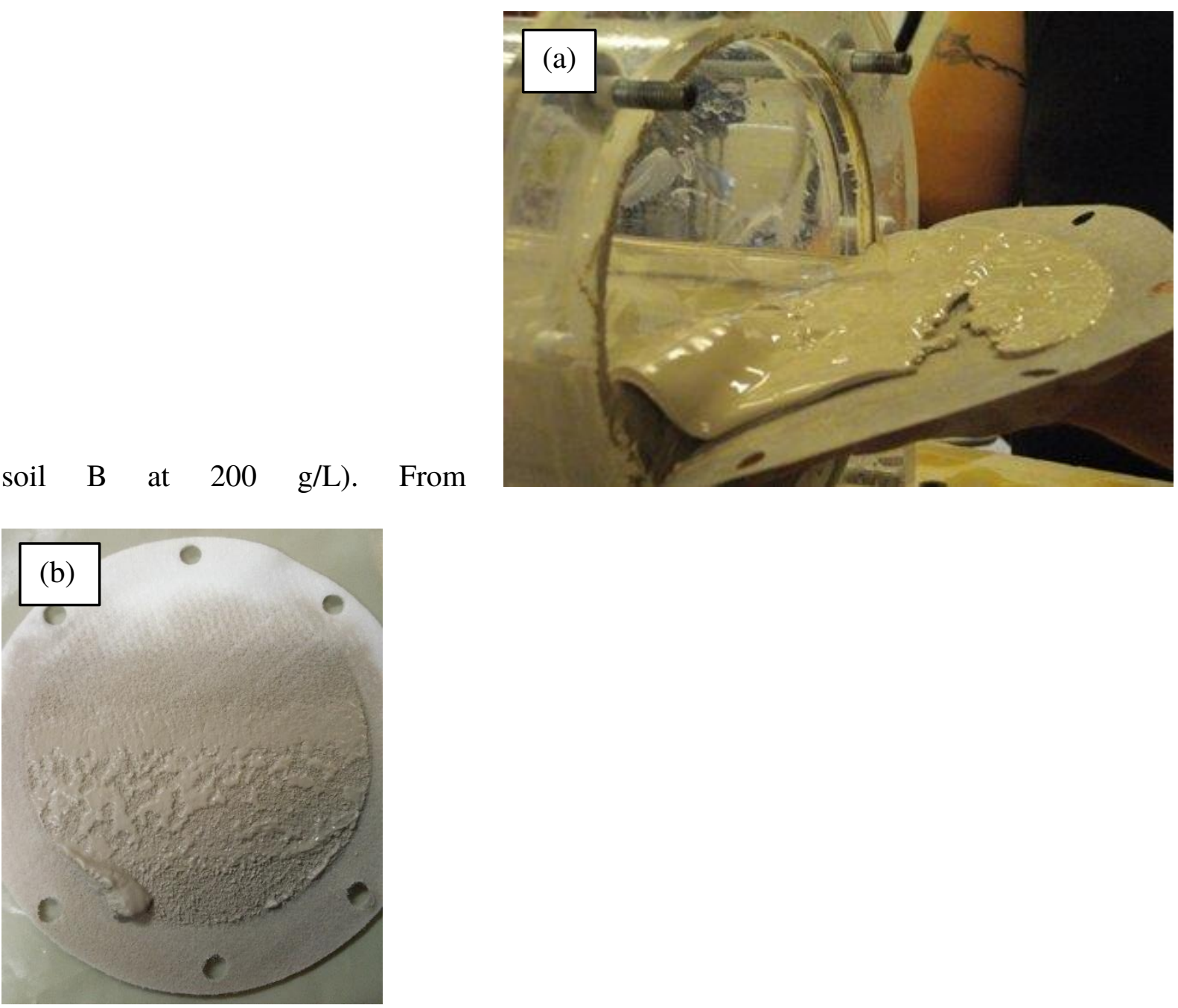

357 Figure 5 (a) it can be seen that the filter cake is well formed, despite the settling of particles.
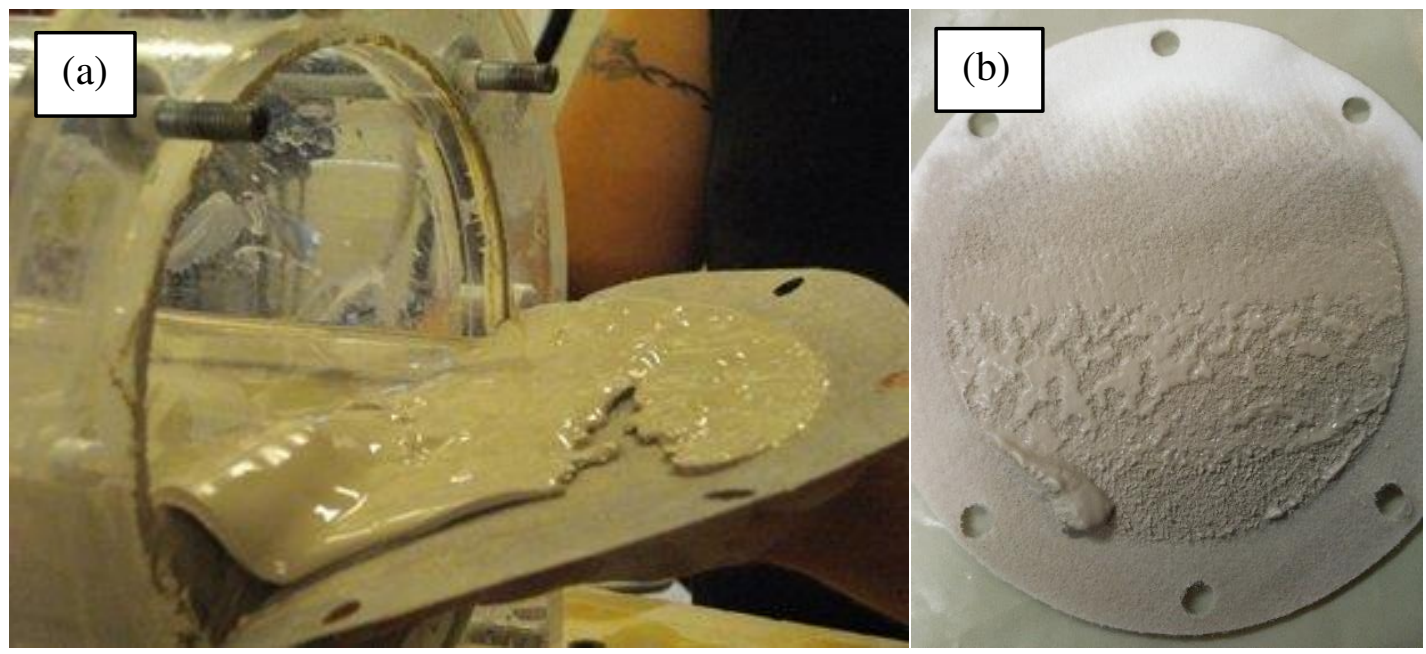

359 Figure 5 (b) it can be seen that the filter geotextile was not able to create a filter cake, and thus

360 the cell was not filled. With a vertical cell (and horizontal filter geotextile), sedimentation and 
362 formation.
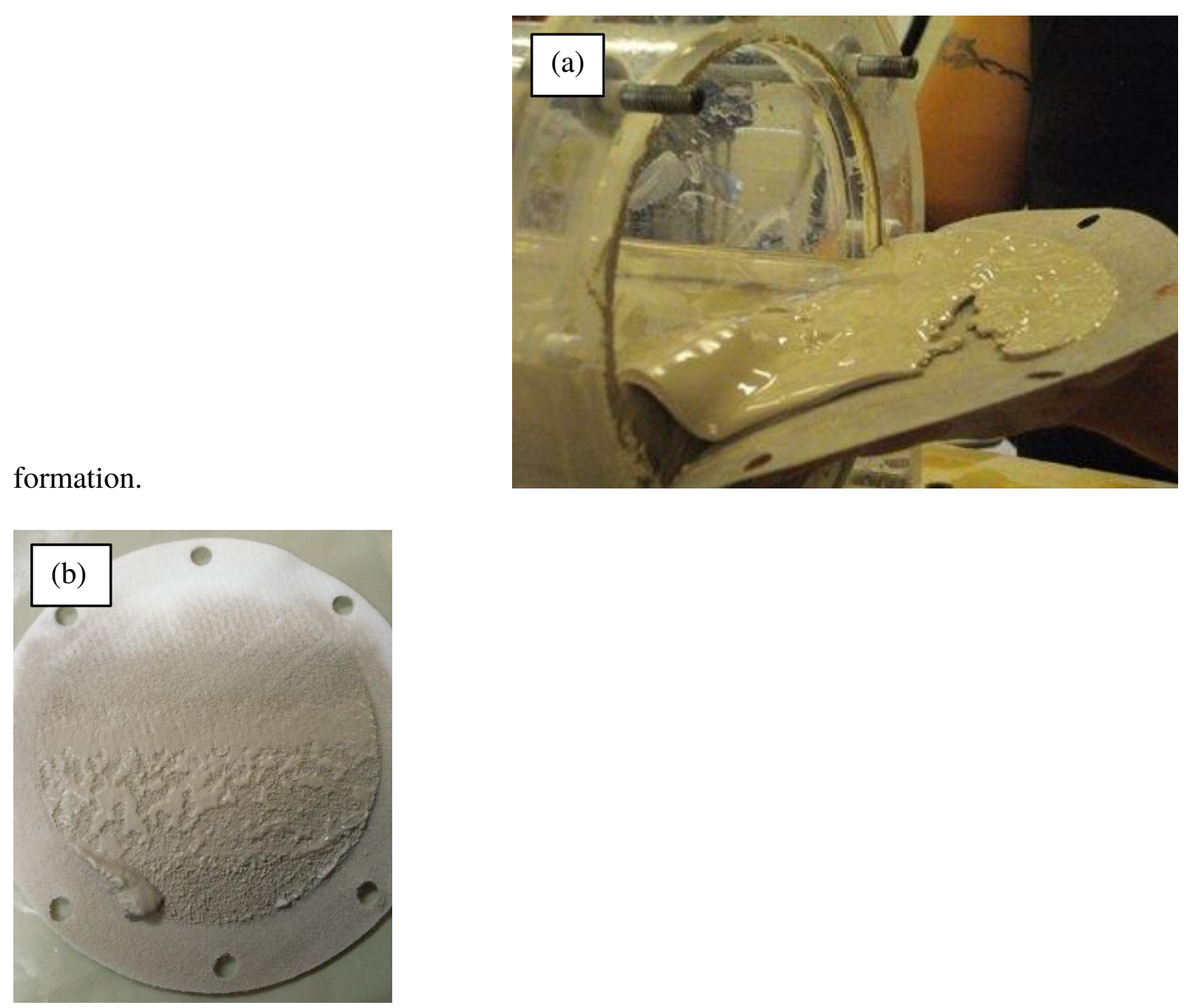

364 Figure 5 confirms the benefit of the vertical orientation of the geotextile to study the creation 365 of the filter cake by separating filtration from the settling and sedimentation of fines inside the 366 cell.

\subsubsection{Parameters MONitored FOR Characterising GeoteXtile-} CONTROLLED FILTRATION

370 When filtration is established, one can evaluate and compare the behaviour of the various

371 systems based on the three criteria given in the introduction. 


\subsection{RESULTS OF THE EXPERIMENTS: COMPARISON OF THE VARIOUS GEOTEXTILES}

373 This analysis considers only those tests that allowed the given filtration system to be 374 characterised: for constant-flow conditions, the tests in which the cell was not filled are excluded, because in this case we consider that no stable filtration system was established.

\subsubsection{EFFICIENCY OF FILTRATION OF CUMULATIVE MASS THAT PASSES THROUGH}

\subsubsection{CONSTANT-FLOW CONDITIONS}

For the well-graded soil $\mathrm{B}$, the data given in Table 5 show that, because of the low concentrations in most of the tests, the cell was not filled. The coarser particles settled in the cell before reaching the geotextile filter, and then the finest particles in suspension that reached the filter were too small to be filtered and/or to create a filter cake. Figure 5 shows a view of the cell after the test in constant-flow conditions; the effect of the sedimentation and settling inside the cell is apparent. A large quantity of fines filled the bottom half of the cell. It is interesting to evaluate the theoretical settling of the particles during the test. The constant flow $F_{w}=0.5 \mathrm{~L} / \mathrm{min}$; therefore, considering the $150 \mathrm{~mm}$ diameter of the cell and its length of 500 $\mathrm{mm}$, the "transit time" $t_{t}$ necessary for a fine particle to transit from the cell entrance to the geotextile filter surface is 17 minutes, $40 \mathrm{~s}$. Considering that (1) the entrance of the cell is opposite the filter at the top of the cell (Figure 3) and that (2) the settling speed of the particles can be calculated, assuming that the particles are spherical, the size of the particles capable of reaching the filter may be determined. Clearly, over the duration of the test, the coarser particles fill the cell progressively from the bottom, which reduces the effective volume of the cell and thereby reduces the transit time $t_{\mathrm{t}}$ of the fines, assuming the flow $F_{w}$ remains constant at 0.5 $\mathrm{L} / \mathrm{m}$. 
395 Nevertheless, in a first approach, the very beginning of the test, when the coarser particles have not yet begun to fill the bottom of the cell, is evaluated as follows: Equation (5) assumes that the particles are spherical. The effect of high particle concentration on settling velocity is taken into account according to Equation (6) and allows the theoretical hindered settling $S_{\text {theo }}\left(t_{t}\right)$ during the transit time to be determined as a function of particle diameter. If $S_{\text {theo h }}\left(t_{t}\right)$ exceeds the diameter of the cell, the corresponding particle will not reach the filter. Table 7 shows that, 401 theoretically, if the particles are considered spherical, the smallest particles (e.g., with a diameter $D_{\mathrm{h}}=10 \mu \mathrm{m}$ or smaller) will reach the filter, but the largest particles (e.g., with a diameter $D_{\mathrm{h}}=20 \mu \mathrm{m}$ or larger) will not reach the filter and will accumulate at the bottom of the cell.

Considering (i) that $20 \%$ of the particles with the initial granulometry of the soil B and that pass through the filter have a diameter $\leq 10 \mu \mathrm{m}$ and (ii) that only particles with a diameter $\leq 10 \mu \mathrm{m}$ reach the filter, the filtration system should theoretically produce a sludge with fine particles $(\leq 10 \mu \mathrm{m})$ with a concentration of fines much lower than the nominal concentration: $14 \mathrm{~g} / \mathrm{L}$ (instead of $70 \mathrm{~g} / \mathrm{L}$ nominal), $20 \mathrm{~g} / \mathrm{L}$ (instead of $100 \mathrm{~g} / \mathrm{L}$ nominal), $40 \mathrm{~g} / \mathrm{L}$ (instead of $200 \mathrm{~g} / \mathrm{L}$ nominal) and $60 \mathrm{~g} / \mathrm{L}$ (instead of $300 \mathrm{~g} / \mathrm{L}$ nominal).

411 Nevertheless, with these very specific conditions, Table 5 shows that only the geotextile 412 NWTB-1 allows the retention of fines in suspension and the creation of a filtration system for 413 the two highest nominal concentrations (200 and $300 \mathrm{~g} / \mathrm{L}$ ). This result is probably linked to both 414 the small opening size and the specific structure of this geotextile. Conversely, for uniform soil 415 A, better filtration occurs because of the creation of a filtration system in most of the tests (see 416 Table 5). This result is probably linked to the type and size of particles. In this case, Figure 2 417 shows that $80 \%$ of the particles of soil $\mathrm{A}$ are less than $10 \mu \mathrm{m}$ in diameter. If, as for soil $\mathrm{B}$, the 418 particles may be considered spherical, the evaluation of particle settling inside the cell during 419 the tests is similar. In this case, as presented in Table 7, 80\% of the particles in suspension in 
the cell would reach the geotextile filter, explaining the creation of the filter cake in most of the

421 tests. Thus, the data of Table 5 support the following conclusions, drawn for the tested filter

422 geotextiles, soils and experimental conditions (flow rate, length of the filtration cell, etc.):

423 - The geotextiles with larger opening sizes (NWMB-1; $\mathrm{O}_{90}=91 \mu \mathrm{m}$ and $\left.\mathrm{W}-1 ; \mathrm{O}_{90}=109 \mu \mathrm{m}\right)$

424 cannot block the fines, and the cell cannot be filled.

425 - For the other geotextiles, filtering occurs, but the mass of the sludge that passes through the

426 filter is less than the theoretical prediction. Ranking the geotextiles from those with a large 427 reduction compared with theory to those with a small reduction gives, assuming equal 428 concentration (100 g/L): NWTB-2, NWTB-1, NWMB-2 and W-2. Similarly, for geotextile 429 NWTB-1, less sludge passes through the filter as the concentration increases. These results are 430 also reflected in Figure 6 by using the efficiency ratio, which is the solid mass retained in the 431 filtration cell divided by the mass of the sludge that passes through the geotextile.

432 These results are obtained for the flow rate of $0.5 \mathrm{~L} / \mathrm{min}$. Higher or lower flow rate would have 433 changed the transit time necessary for a fine particle to transit from the cell entrance to the 434 geotextile filter surface, and thus, regarding sedimentation phenomenon, conditions to create a 435 filter cake.

\subsubsection{CONSTANT-HEAD CONDITIONS}

437 For the well-graded soil B, part 1 of Table 6 shows that, for a large number of tests (11 out of 438 20) the filtration system did not stabilise and a large amount of fines continued to pass through 439 the geotextile filter at the end of the test. Nevertheless, the number of tests where stable filtration 440 systems developed provides enough data to compare the behaviour of these filtration systems. 441 As presented in section 2.2, a filtration system can be evaluated by the quantity of sludge that 442 passes through it and, more precisely, by the mass of particles that pass through it (this is the 443 first criterion defined in the introduction). For several geotextiles, Figure 7 compares the mass 
444 of the sludge that has passed through the given geotextile by the end of the test as a function of 445 the initial sludge concentration (tests were stopped based on visual observation) and for 446 constant-head conditions. These results allow the different geotextiles to be compared:

447 - The mass of the sludge, and similarly the mass of fines, that passes through a geotextile 448 decreases with increasing concentration of fines in the sludge; this can be explained by a more 449 rapid formation of the filter cake in contact with the geotextile due to the higher concentration 450 of fines in the sludge.

$451 \quad$ - $\quad$ The geotextiles with larger opening size (e.g., NWMB-1) let more sludge, and thus more 452 fines, pass through during the test.

453 - The geotextiles with smaller opening size (e.g., NWTB-1, W-2, NWMB-2) reduce the 454 mass of fines that pass through the filter during the test, whereas the mass of the sludge that 455 passes through is not negligible, which means that water passes through the established 456 filtration system.

457 - If geotextiles with a thermally bonded structure allow a better stabilisation than the 458 mechanically bonded geotextiles, it appears that, for a given geotextile structure, a small 459 opening size is a key parameter to create a stable filtration system, which is confirmed by the 460 better behaviour of NWTB-1 and NWTB-2 $\left(\mathrm{O}_{90}<50 \mu \mathrm{m}\right)$ compared with NWTB-3 and 461 NWTB-4 $\left(\mathrm{O}_{90}=61\right.$ and $\left.140 \mu \mathrm{m}\right)$ for the thermally bonded structure and NWMB-2 $\left(\mathrm{O}_{90}=54\right.$ $462 \mu \mathrm{m})$ compared with NWMB-1 $\left(\mathrm{O}_{90}=91 \mu \mathrm{m}\right)$.

463 - By comparing the results from the NWTB and W geotextiles on one side and the 464 NWMB geotextiles on the other, and by considering that the constrictions generally number 465 between 25 and 50 for mechanically bounded nonwoven geotextiles and are equal or close to 466 unity for woven and thermally bonded nonwoven geotextiles, the number of constrictions 467 cannot be considered a relevant parameter for evaluating the filtration of fines in suspensions. 
However, because the time required to create a filter cake depends on the type of geotextile, it

469 is of interest to evaluate the average flows that pass through the geotextile (flow of sludge, solid

470 fines, and water) and to study how these parameters evolve (this is the second criterion defined

471 in the introduction). For the second series of tests, which lasted 90 minutes (Table 6, part 2),

472 three parameters became linear with time as soon as the filter system was established and

473 remained so until the end of the test (90 minutes). The tests were finalised after running for 90

474 minutes. In Table 6, part 2, the asterisk corresponds to a test that started with constant-flow 475 conditions and, when the pressure in the cell reached $10 \mathrm{kPa}$, continued with constant-head 476 conditions. The time required to establish the filter system may depend on the geotextile; the 477 maximum time observed was 12 minutes.

478 Table 8 presents the average sludge mass, solid mass and water mass that passes through the 479 geotextile filter after the cell is filled, and the filter system is created. Part (a) of Table 8 compares the concentration of fines in the sludge for different geotextiles $\left(C_{\mathrm{s}}=500 \mathrm{~g} / \mathrm{L}\right)$. The geotextiles with the smallest opening size (NWTB-1 and W-2) block the fines and let water pass through, whereas the geotextile with larger opening size (NWMB-2) continues to let fines pass through at a constant rate until the end of the test. Part (b) of Figure 6 shows the influence 484 of the solid concentration of the sludge for the geotextile NWTB-1. For all initial concentrations 485 tested $\left(C_{\mathrm{s}}=400,500\right.$ and $\left.700 \mathrm{~g} / \mathrm{L}\right)$, no fines pass through the geotextile, and the amount of water that passes through the geotextile decreases as the initial concentration increases. These observations suggest that the characteristics of the filter cake may depend both on the 488 concentration of fines in the sludge and on the type of geotextile. A preliminary characterisation 489 of the filter cakes is presented in section 4.3.

490 To evaluate the environmental impact of the effluent as defined in the introduction, we look at 491 the filter efficiency, which is defined as the ratio of solid mass in the filtration cell to sludge 492 mass that passed through the geotextile. These quantities were measured at the end of the phase 
493 in which filtration was determined by the geotextile and later during the phase in which

494 filtration was determined by the filter cake (the second criterion defined in the introduction). A

495 higher ratio corresponds to a better filter efficiency (Figure 8). A general trend is apparent in

496 which the smaller opening size corresponds to better efficiency, and for similar opening sizes

497 the thermally bonded structure gives the best efficiency. This trend is more deeply analysed

498 along with the characterisation of the filter cakes in section 4.3.

499 Figure 9 shows the results obtained for uniform soil A. For soil B, the first series of tests allows 500 the different geotextiles to be compared; the results show that both the mass of the sludge and

501 the mass of fines that pass through the geotextile decrease with increasing concentration of fines

502 in the sludge. The geotextiles with larger opening size (e.g., NWMB-1) allow more sludge to 503 pass through during the test, and thus more fines, whereas the geotextiles with smaller opening 504 size (e.g., NWTB-1, W-2, NWMB-2) reduce the mass of fines that pass through. However, the 505 results for filter efficiency for soil A are less systematic than those for soil B.

506 Table 9 shows the effect of the solid concentration of the sludge for geotextile NWTB-1 507 evaluated based on the second series of tests (i.e., the 90-minute tests). As was the case for soil $508 \mathrm{~B}$, the results for geotextile NWTB-1 indicate that no fines pass through and that the water flux 509 passing through decreases with increasing initial concentration of fines. Nevertheless, for 510 uniform soil A, the total mass of the sludge that passes through is less than that for the well511 graded soil B. These observations confirm the utility of the preliminary characterisation of the 512 filter cakes in section 4.3, which should help to better understand the local behaviour of the 513 filtration process.

\subsubsection{PARTICle-SIZE DISTRIBUTION OF SOILS THAT PASS THROUGH THE FILTER}

515 The results of the tests done when the filter system was stabilised and when the cake was formed 516 indicate that the mass of fines that passed through remained very low; thus, it was not possible 
to accurately measure the particle-size distribution of the soil that passed through the filter.

518 Therefore, measurements were made for tests in which a reasonable mass of soil passed through 519 the filter. Thus, for some of the tests used for this evaluation, the filtration system was not 520 stabilised, so the geotextile was serving more as a sieve than as a filter. For soil B,

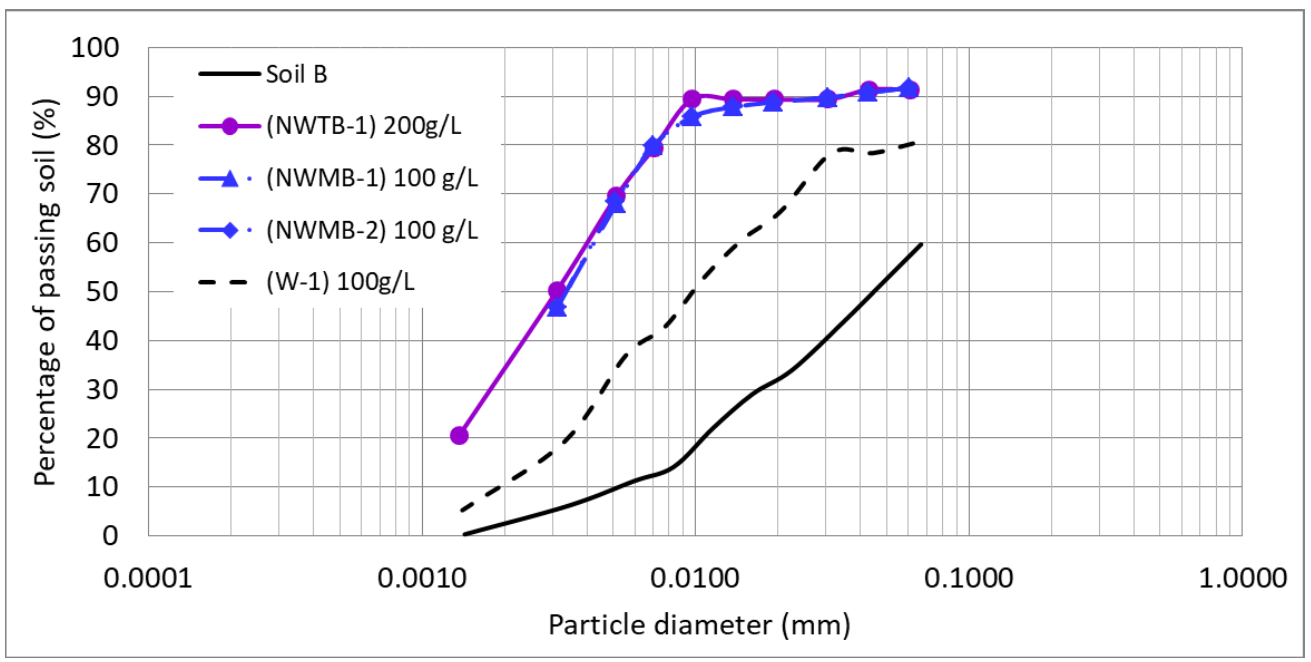

522 Figure 10 shows the measured particle-size distribution of the soil that passes through the filter 523 under constant-flow conditions. The analysis of the grain-size distributions of this soil shows 524 that, for all nonwoven geotextiles with small opening sizes ( $<50$ to $91 \mu \mathrm{m})$, the soil consists of 525 fine particles of diameter less than $10 \mu \mathrm{m}$, which are not blocked by the geotextile in the absence 526 of a filter cake. For woven geotextiles with a larger opening size $(109 \mu \mathrm{m})$, larger particles with 527 diameters up to 30 to $40 \mu \mathrm{m}$ pass through the geotextile, confirming that, without a filter cake, 528 the geotextile acts as a sieve. In this respect, these results confirm the advantage of geotextiles 529 with small opening size.

\subsection{PRELIMINARY CHARACTERISATION OF THE FILTER CAKE}

531 This characterisation is linked to the third criterion described in the introduction (i.e., once 532 formed, the filter cake must be the most permeable possible). For the second series of 90 -minute 
533 tests,
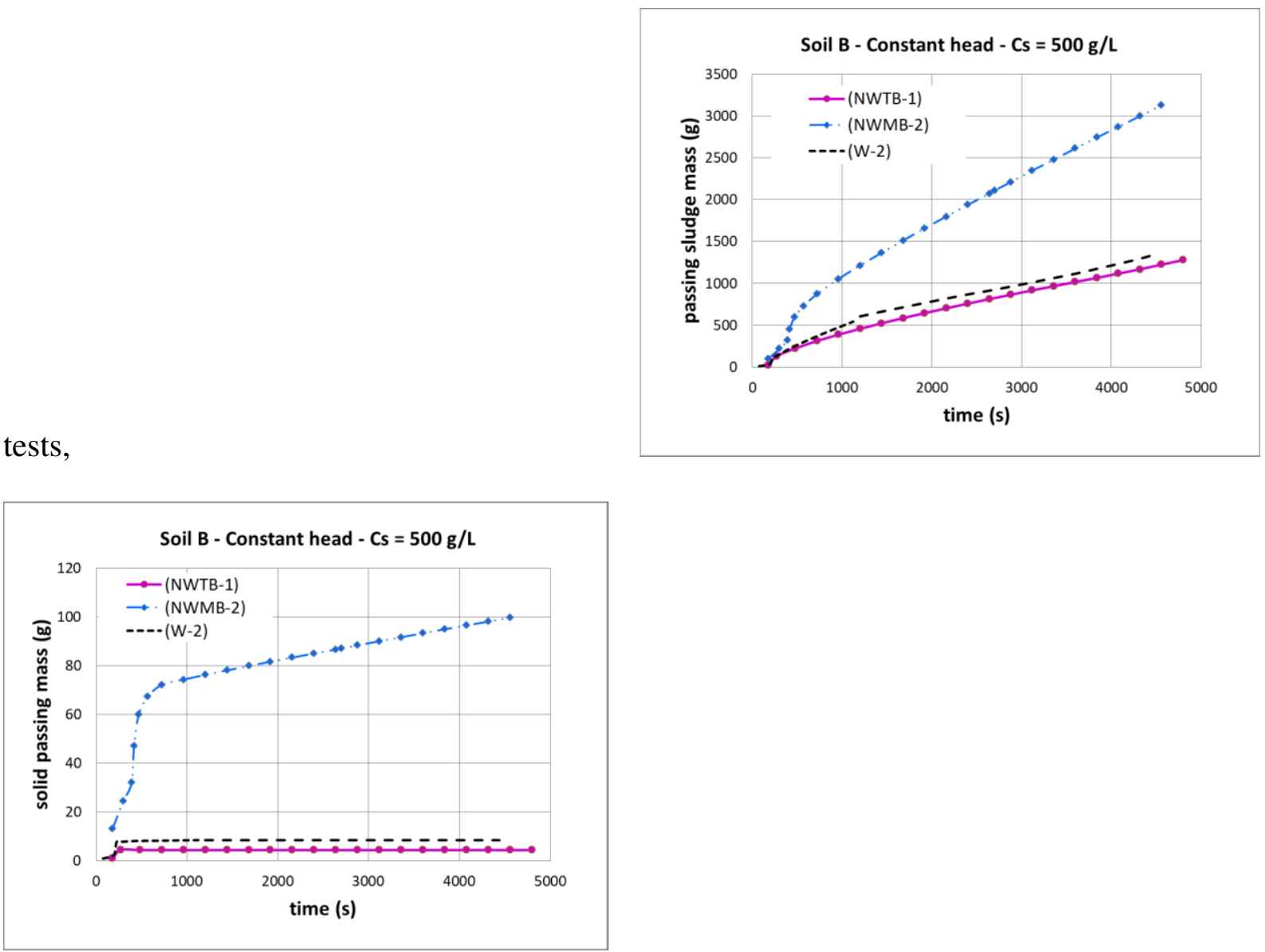

535 Figure 11 shows the mass of the sludge that passes through the given geotextile as a function

536 of time. For geotextile NWMB-2, the fines continue to pass through the geotextile for the entire

537 duration of the test, whereas geotextiles NWTB-1 and W-2 block the fines after a certain time

538 but still allow water to pass, confirming that the filter-cake behaviour should be evaluated more

539 precisely. As discussed in section 2.2, during the test, when the filter cake appears on the

540 upstream face of the geotextile, the filtration process is controlled by the build-up of head loss,

541 which leads to a pressure drop across the filter cake. This pressure drop may be estimated by

542 Equation (4), and the interpretation of the experimental $t / V$ versus $V$ graph allows the specific

543 filter-cake resistance $\alpha$ to be determined. Figure 12 shows the graphs of $t / V$ versus $V$ for

544 geotextile NWTB-1 (for both soils A and B and for various concentrations) and for various

545 geotextiles for soil B and a concentration of $500 \mathrm{~g} / \mathrm{L}$ (see Table 6, part 2). In the early stage of

546 filtration, the curves are nonlinear with a decreasing trend that can be interpreted as the filter- 
cake-stabilisation period. After this period (delimited by a black arrow on the graphs), the filter

548 cake is well established, and the model described by Equation (4) can be applied. In other words,

549 the curves become linear with a positive slope. This use of Equation (4) to model the filtering

550 tests is validated for both soils A and B and for all three geotextile filters (NWTB-1, NWMB-

5512 , W-2). According to Leu (1986), the specific filter-cake resistance $\alpha$ ranges from $1 \times 10^{9} \mathrm{~m} / \mathrm{kg}$

552 (for easy filtration) to $1 \times 10^{13} \mathrm{~m} / \mathrm{kg}$ (for difficult filtration). Assuming a viscosity of $1.002 \times$

$55310^{-3} \mathrm{~N} \mathrm{~s} / \mathrm{m}^{2}$, Table 10 shows the specific filter-cake resistance as determined by the second

554 series of 90-minute tests. The double asterisk corresponds to a test that was started under

555 constant-flow conditions and, when reaching $10 \mathrm{kPa}$ inside the cell, continued under constant-

556 head conditions. The test was finalised after a total duration of 90 minutes. The specific filter-

557 cake resistance for the well-graded soil B falls between $8.8 \times 10^{8}$ and $3.6 \times 10^{10} \mathrm{~m} / \mathrm{kg}$ for all

558 geotextiles and concentrations tested, whereas for uniform soil A the values calculated are

559 higher: between $4.7 \times 10^{11}$ and $1.1 \times 10^{12} \mathrm{~m} / \mathrm{kg}$. These results are encouraging, at least for the

560 well-graded soil for which the NWTB-1, NWMB-2 and W-2 specific filter-cake resistances $\alpha$

561 are calculated to lie in the range of easy filtration. Note that the incompressibility assumption

562 linked to the equation from Kozeny (1927) still needs to be verified. The compressibility of the

563 cake is given by the slope of the curve

564

$$
\log (\alpha)=f\left(\ln \left(\Delta p_{\mathrm{f}}\right)\right)
$$

565 where $\alpha$ is the specific filter-cake resistance, and $\Delta p_{\mathrm{f}}$ is the pressure drop through the filter cake.

566 The range of compressibility of the cake varies from zero for incompressible cakes to near unity

567 for highly compressible cakes. For incompressible filter cakes, the rate of filtration is directly

568 proportional to the filtration pressure, the filtering surface, viscosity and the amount of cake.

569 For a compressible cake, the rate of filtration does not increase proportionally with an increase

570 in pressure. 
The measurement of the compressibility by tests at different pressures (not yet undertaken in

572 this study), will help to confirm this first approach for the specific filter-cake resistances and to evaluate how pressure increase affects filtration rates. Nevertheless, this first evaluation seems encouraging and confirms that geotextiles showing a good behaviour over long-term tests should continue to be investigated.

\section{DISCUSSION AND CONCLUSIONS}

The present study gives a better understanding of how the geotextile characteristics affect filtration when subjected to a flow of fines in suspension and without flocculent, geotextile being vertical versus the flow being horizontal. Various parameters have been analysed and discussed in detail: the type of soil (well graded or uniform), the concentration of fines (seven different concentrations ranging from 70 to $700 \mathrm{~g} / \mathrm{L}$ ), the type of water flow (constant flow or constant head) and the type of geotextile (three types, namely, thermally bonded nonwoven, needle-punched nonwoven and woven). Based on an analysis of the soil retained and that passed by the filter geotextile, we compared the different filtration systems. This approach led to a three-stage view of geotextile systems for filtering fine particles in suspension: (1) stabilisation of the filtration process, with a significant and rapid increase in the concentration of solids upstream of the geotextile; (2) an initial loss of fines through the geotextile that is of limited duration, ensuring an effluent with an acceptable environmental impact; and (3) an acceptable long-term water permeability of the filtration system.

The results of the constant-flow experimental study show that the horizontal orientation of the cell and the vertical orientation of the geotextile allow sedimentation/settling to be separated from filtration. Nevertheless, this orientation of the device modifies and reduces the concentration of particles in contact with the geotextile and explains the large number of tests for which the cell could not be filled. Moreover, results interpretation of tests at constant flow 
conditions were made following the selected flow rate of $0.5 \mathrm{~L} / \mathrm{min}$, and, changing the flow rate

596 could change the conditions to create a filter cake.

597 Two phases of filtration were analysed: (i) filtration controlled by the geotextile, and (ii)

598 filtration controlled by a filter cake. For constant flow, when filtration is controlled by the 599 geotextile, the following conclusions can be drawn:

600 - The tests using the well-graded soil B show that only geotextile NWTB-1 retains the fines 601 in suspension and allows the creation of a filtration system for the two highest 602 concentrations (200 and $300 \mathrm{~g} / \mathrm{L}$ ); this result is attributed to both the small opening size in

603 this geotextile and its specific structure.

604 - The tests using the uniform soil A show that

$605 \quad-\quad$ the geotextiles with larger opening sizes $\left(\mathrm{NWMB}-1 ; \mathrm{O}_{90}=91 \mu \mathrm{m}\right.$ and $\mathrm{W}-1 ; \mathrm{O}_{90}=109$

606 $\mu \mathrm{m})$ cannot block the fines and the cell cannot be filled;

607

608

609

- for geotextiles with opening size $\mathrm{O}_{90} \leq 63 \mu \mathrm{m}$, filtration allows less sludge mass to pass through than is predicted by theory, and this difference in mass between experiment and theory is used to rank the geotextiles (from largest difference to smallest), for the same concentration of $100 \mathrm{~g} / \mathrm{L}$, as NWTB-2, NWTB-1, NWMB-2, W-2;

- as the concentration increases, the mass of the sludge that passes through geotextile

613 When filtration is controlled by a filter cake, for constant-head conditions, the tests with the 614 well-graded soil B show that the following results:

$615-$ For a concentration $C_{\mathrm{s}}=500 \mathrm{~g} / \mathrm{L}$ of fines in the sludge, geotextiles NWTB-1 and W-2 616 block the fines and allow water to pass through, whereas geotextile NWMB-2 continues 617 to allow fines to pass through until the end of the test; the characteristic opening sizes 618 of all three geotextiles are very small $\left(\mathrm{O}_{90} \leq 63 \mu \mathrm{m}\right)$, but the structures differ. The thinner thermally bonded geotextile (and metallic sieve) is less porous than the slightly 
thicker mechanically bonded geotextile; this difference may explain the different filtration behaviours.

- For geotextile NWTB-1 with initial concentrations $C_{\mathrm{s}}=400,500$ and $700 \mathrm{~g} / \mathrm{L}$, no fines pass through and the mass of water that passes through decreases as the initial concentration increases.

- To evaluate effluent quality to determine its environmental impact, we define the filter efficiency as the ratio of solid mass in the filtration cell to sludge mass that passed through the geotextile. It has been shown that smaller geotextile opening size leads to

This work proposes a method to preliminary evaluate the specific filter-cake resistance. The equation derived from liquid-solid-separation theory was shown to provide an appropriate model for the tests of filtering clayey sludge through geotextiles. Note that this study could not verify the assumption of an incompressible filter cake. Nevertheless, if this assumption is 634 accepted, this analysis gives a specific filter-cake resistance $\alpha=8.8 \times 10^{8}$ to $3.6 \times 10^{10} \mathrm{~m} / \mathrm{kg}$ 635 (for well-graded soil), which is promising for the geotextiles evaluated herein. In conclusion, this experimental study shows that the filtration by geotextiles of fines in suspension and without flocculants remains a delicate topic and calls for a thorough evaluation and a proper design of the geotextile. The results are significantly influenced by the orientation 639 of the geotextile filter (vertical or horizontal) from the settling of the particles during the test 640 and the selected flow rate for tests at constant flow conditions.

641 For a well-graded soil (such as soil B), when the concentration of fines is low, and the hydraulic 642 conditions correspond to constant flow, only geotextile NWTB-1 allows a filter cake to build 643 progressively and stabilise over time. The other geotextiles tested do not block the fines. When 644 the concentrations increase, and the hydraulic conditions correspond to constant head, the 
645 geotextiles with the smallest opening size (NWTB-1 and W-2) produce a stabilised filter system 646 that, after a short time, blocks the fines in suspension while still letting water pass through. The 647 other geotextile (NWMB-2), which also leads to the creation of a filter cake, continues to allow 648 fines to pass through for the entire test and, thus, is inferior with respect to the downstream 649 filtration criteria.

650 For uniform soil A, the results of the tests show a relatively good performance of the geotextiles 651 performing correctly with the well-graded soil B. Nevertheless, extrapolation to other uniform 652 soils should be handled with care because the results of the tests correspond to the relative 653 positioning of the average diameter of the soil and of the characteristic opening size of the 654 geotextiles, which in the present study can be considered favourable. Other relative values may 655 certainly give very different results.

656 Considering all the tests done for this study, it appears that, for the soils tested, the thin 657 geotextiles with the smallest opening sizes $\left(\mathrm{O}_{90} \leq 60 \mu \mathrm{m}\right)$ give the most promising results for 658 filtering fines without flocculants. Of these geotextiles, the thermally bonded nonwoven 659 structure provides the best compromise between opening size and geotextile thickness and 660 suitable support for a filter cake to allow long-term permeability. In addition, with a well-graded 661 soil, this structure seems to offer the best filtering characteristics for the largest range of 662 concentration of fines. In terms of practical applications, this study gives worthwhile results for 663 the configuration consisting of a vertical filter filtering a horizontal flux of clayey sludge (e.g., 664 dragging sediment behind a filtering wall, filtering clayey sludge against the side slope of a 665 tailing pond, or filtering clayey sludge injected into a textile tube). 


\section{ACKNOWLEDGEMENTS}

669 The authors want to thank Hajer Bannour (Irstea) for her important participation to this work 670 and the realisation of some of the tests presented in this paper.

671

\section{7. NotATiON}

$673 A$

effective area of filtration $\left(\mathrm{m}^{2}\right)$

$674 \alpha$

specific filter cake resistance $(\mathrm{m} / \mathrm{kg})$

$675 C_{\mathrm{s}}$

concentration of solid fines in the sludge $\left(\mathrm{kg} / \mathrm{m}^{3}\right)$

$676 \quad D_{\mathrm{h}}$

hydraulic diameter of a particle $(\mathrm{m})$

$677 \varepsilon$

ratio of the volume of liquid over the volume of sludge

$678 \quad F_{\mathrm{w}}$

flow of sludge $\left(\mathrm{m}^{3} / \mathrm{s}\right)$

$679 g$

acceleration of gravity $\left(\mathrm{m} / \mathrm{s}^{2}\right)$

$680 Q_{\text {s }}$

theoretical flux (with no filtration) of solid particles passing through the

681 geotextile per second $(\mathrm{kg} / \mathrm{s})$

$682 m_{\mathrm{pA}}$ mass of particles passing through the geotextile $\mathrm{A}(\mathrm{kg})$

$683 m_{\mathrm{rA}}$ retained mass of particles by the geotextile $\mathrm{A}(\mathrm{kg})$

$684 \mu$ viscosity of the liquid phase of the suspension $\left(\mathrm{N} \mathrm{s} / \mathrm{m}^{2}\right)$

$685 n$ exponent

$686 \Delta p_{\mathrm{cf}}$ characteristic pressure drop for the cake formation $(\mathrm{Pa})$

$687 \Delta p_{\mathrm{f}}$ pressure drop through the filter cake $(\mathrm{Pa})$

$688 R_{\mathrm{m}}$ filter medium resistance $\left(\mathrm{m}^{-1}\right)$

$689 \rho_{\mathrm{p}}$ density of the particle $\left(\mathrm{kg} / \mathrm{m}^{3}\right)$

$690 \rho_{\mathrm{w}}$ density of water $\left(\mathrm{kg} / \mathrm{m}^{3}\right)$

$691 S_{\text {theo }}\left(t_{\mathrm{t}}\right) \quad$ theoretical hindered settling of the particle during the transit time $t_{\mathrm{t}}(\mathrm{m})$

$692 t \quad$ filtration time (s)

$693 t_{\mathrm{A}} \quad$ time for clogging for the geotextile A (s)

$694 t_{\mathrm{t}}$ 695 "transit time" necessary for a fine particle to transit from the entrance in the $696 \quad \mathrm{~V}$ cell to the surface of the filter geotextile volume of filtrate $\left(\mathrm{m}^{3}\right)$ 

$697 \quad V_{\mathrm{h}}$
hindered settling velocity $(\mathrm{m} / \mathrm{s})$
$698 V_{\mathrm{t}}$
terminal settling velocity of the particle $(\mathrm{m} / \mathrm{s})$

699 


\section{REFERENCES}

701 Aydilek, A., Edil, T., 2003. Long-term filtration performance of nonwoven geotextile-sludge systems. Geosynth. Int. 10, 110-123.

703

Aydilek, A., Oguz, S., Edil, T., 2005. Constriction size of geotextile filters. J. Geotech.

704 Geoenviron. Eng. 131 (1), 28-38.

705

Bourgès-Gastaud, S., Stoltz, G., Sidjui, F., Touze-Foltz, N., 2014. Nonwoven geotextiles to filter clayey sludge: an experimental study. Geotext. Geomembr. 42, 214-223.

Bouthot, O., Vermeersch, O., Blond, E. \& Mlynarek, J., 2002. The number of constrictions concept as aa mean to predict the filtration behavior of nonwoven geotextile filters. Nice,

709 Proc. 7th Int. Conf. on Geosynthetics, 1061-1064.

710 Chi Tien, Bandaru, V., Ramarao, 2011. Revisiting the laws of filtration: an assessment of 711 their use in identifying particle retention mechanisms in filtration. Journal of Membrane 712 Science $383,17-25$.

713 Delmas, P., 2007. Dewatering of waste and contaminated soils by using geotextile tubes. CR 714 of Geo-Environmental Engineering, 7th Japan-Korean-French seminar, 22-24 May.

715 Faure, Y. H., Baudoin, A., Pierson, P., Ple, O., 2006. A contribution for predicting geotextile 716 clogging during filtration of suspended solids. Geotext. Geomembr. 24 (1), 11-20.

717 Giroud, J.P., 1982. Filter Criteria for Geotextiles, Proceedings of the Second International 718 Conference on Geotextiles, Vol. 1, Las Vegas, NV, USA, August 1982, 103-108.

719 Koerner, G., Koerner, R., 2006. Geotextile tube assessment using a hanging bag test. Geotext. 720 Geomembr. 24, 129-137.

721 Kozeny, J., 1927. Über kapillare Leitung des Wassers im Boden,. Berichte Wiener Akademy, 722 Issue 136a, 271p.

723 Kutay, M., Aydilek, A., 2004. Retention performance of geotextile containers confining 724 geomaterials. Geosynth. Int. 11, 100-113.

725 Lawson, C. R., 2006. Geotextile containement for hydraulic and environmental engineering. 726 C.R. of 8th Int. Conf. on Geoynthetics, 41p. 
Le Coq, 1996. Mise en oeuvre et modélisation de médias filtrants à base the fibres minérales pour la filtration des huiles en avionique. PhD Thesis Institut national polytechnique de Grenoble, Ecole française de Papeterie et Industries Graphiques de Grenoble, 280p. Leu, W., 1986. Principles of Compressible Cake Filtration; Encyclopedia of fluid mechanics vol 5. Houston : Gulf Pub. Co., Book Division.

Lydersen, A. L. ,1979. Fluid Flow and Heat Transfer. John Wiley \& Sons ed. New York: s.n, $733357 \mathrm{p}$.

734 Moo-Young, H. K., Gaffney, D. A., Mo, X., 2002. Testing procedures to access the viability 735 of dewatering with geotextile tubes. Geotext. Geomembr. 20 (5), 289-303.

736 Muthukumaran, A. E., Ilamparuthi, K., 2006. Laboratory studies on geotextile filters as used 737 in geotextile tube dewatering. Geotext. Geomembr. 24 (4), 210-219.

738 Sabiri, N.E., Caylet, A., Montillet, A., Le Coq, L., Durkheim, Y., 2017. Performance of 739 nonwoven geotextiles on soil drainage and filtration, Eur. J. Environ. Civ. En, DOI: 10.1080/19648189.2017.1415982.

741 Satyamurthy, R., Bhatia, S., 2009. Effect of polymer conditioning on dewatering 742 characteristics of fine sediment slurry using geotextiles. Geosynth. Int. 16, 83-96.

743 Soo-Khean Teoh, Tan, R. B. H., Chi Tien., 2006. Analysis of cake filtration data - a critical 744 assessment of conventional filtration theory. AIChE Journal 52 (10), 3427-3442.

745 Veylon, G., Stoltz, G., Mériaux, P., Faure, Y. H., Touze-Foltz, N., 2016. Performance of 746 geotextile filters after 18 years' service in drainage trenches. Geotext. Geomembr. 44, 515747533.

748 Weggel, J., Dortch, J., 2012. A model for filter cake formation on geotextiles: Experiments.

749 Geotext. Geomembr. 31, 62-68.

750 Weggel, R., Ward, D., 2012. A model for filter cake formation on geotextiles: Theory. 751 Geotext. Geomembr. 31, 51-61.

752 Weggel, R., Dortcha, J., Gaffney, D., 2011. Analysis of fluid discharge from a hanging 753 geotextile bag. Geotext. Geomembr. 29, 65-73.

754 Yee, T. W., Lawson, C. R., Wang, Z. Y., Ding, L., Liu, Y., 2012. Geotextile tube dewatering 755 of contaminated sediments, Tianjin Eco-City, China. Geotext. Geomembr. 31, 39-50. 
(a)

Pressure drop $\Delta \mathrm{p}$

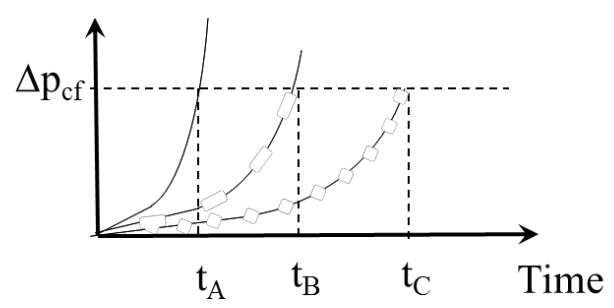

$\Delta \mathrm{p}_{\mathrm{cf}}$ : characteristic pressure drops for cake formation. (b) imposed flow of particles

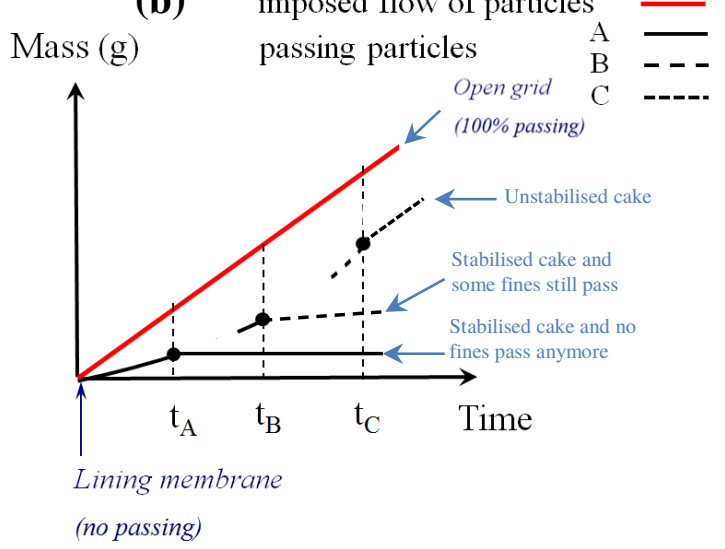

(no passing)

758 Figure 1. (a) Pressure drop as a function of time and (b) mass that passes through geotextile 759 filter as a function of time. $t_{\mathrm{A}}, t_{\mathrm{B}}$ and $t_{\mathrm{C}}$ are the time intervals between the onset of filtration 760 and filter-cake formation for geotextiles A, B and C when exposed to a flow of water charged 761 by particles (no scale). 


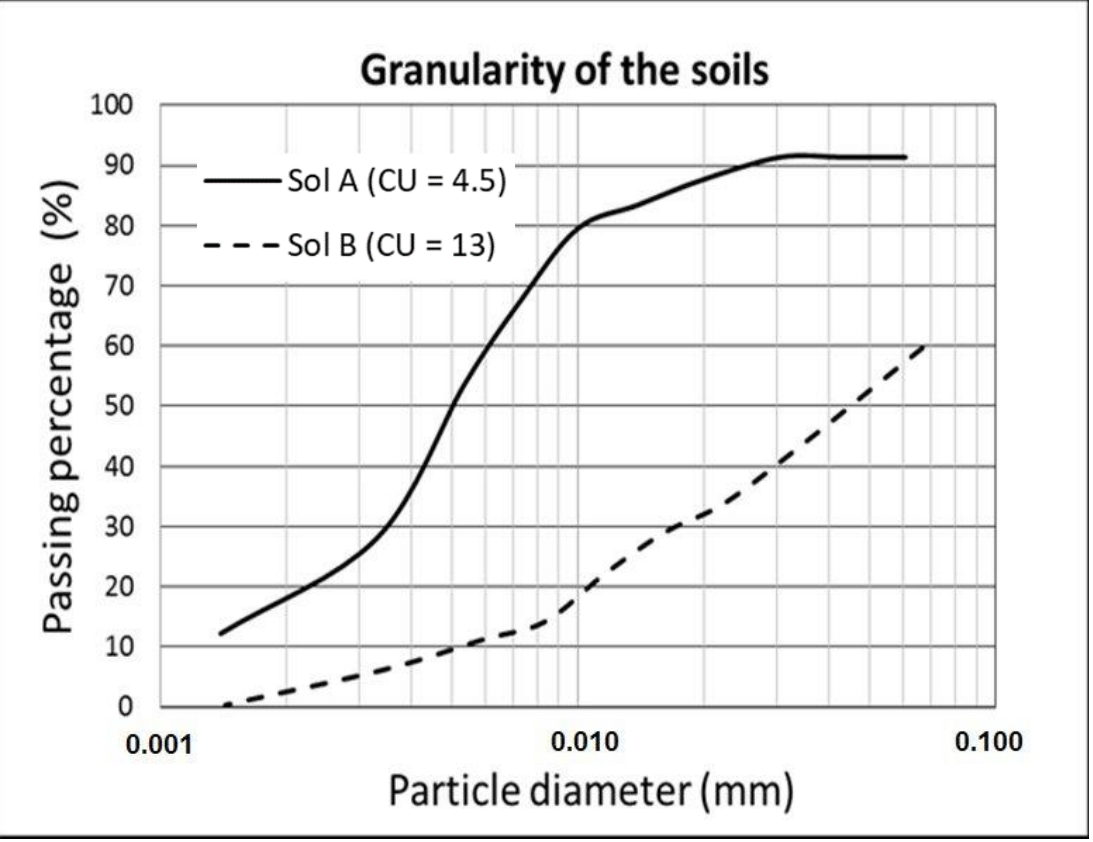

775 Figure 2. Particle-size distribution showing the fraction of particles that pass through the

776 geotextile filter as a function of particle diameter for the two soils used in the filtration tests.

777

778

779

780

781 


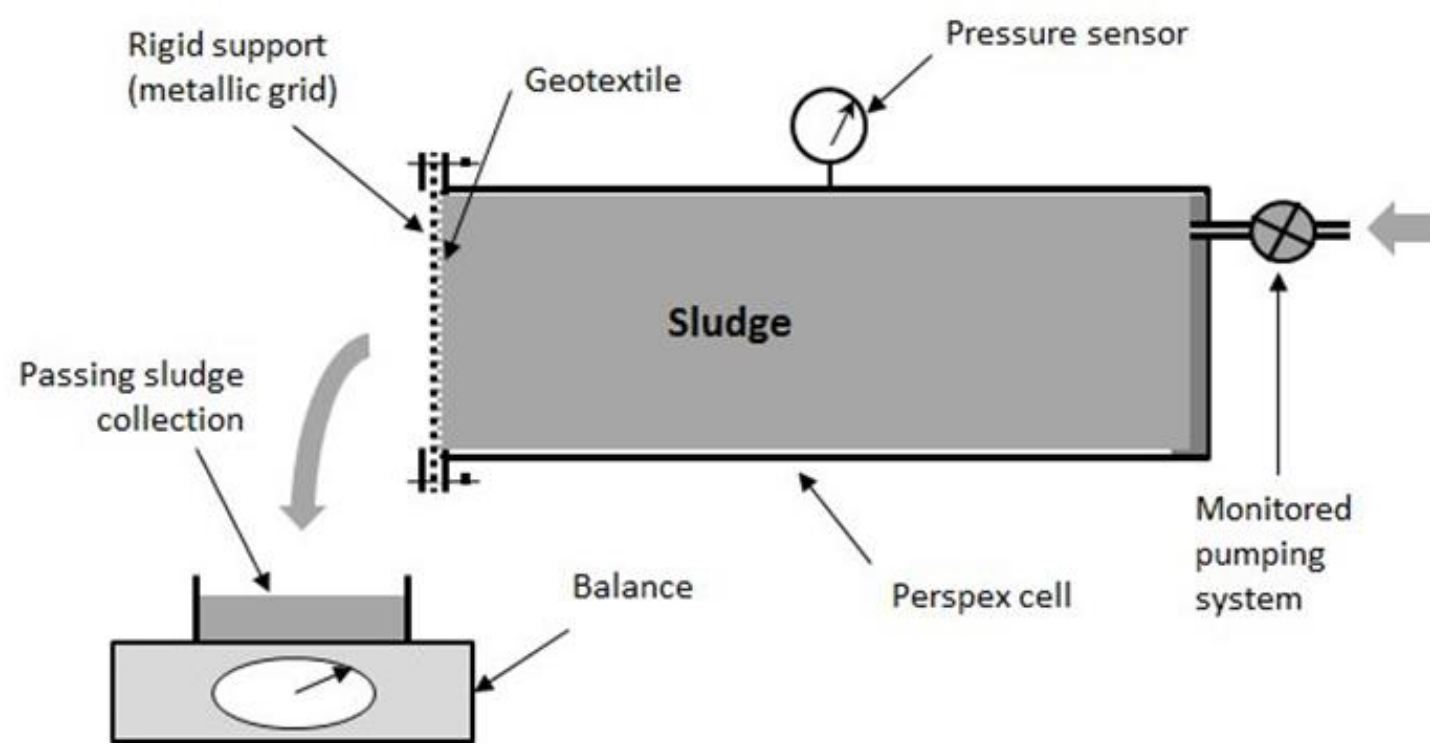

783 Figure 3. Principle of test cell used for filtering sludge (no scale).

784 


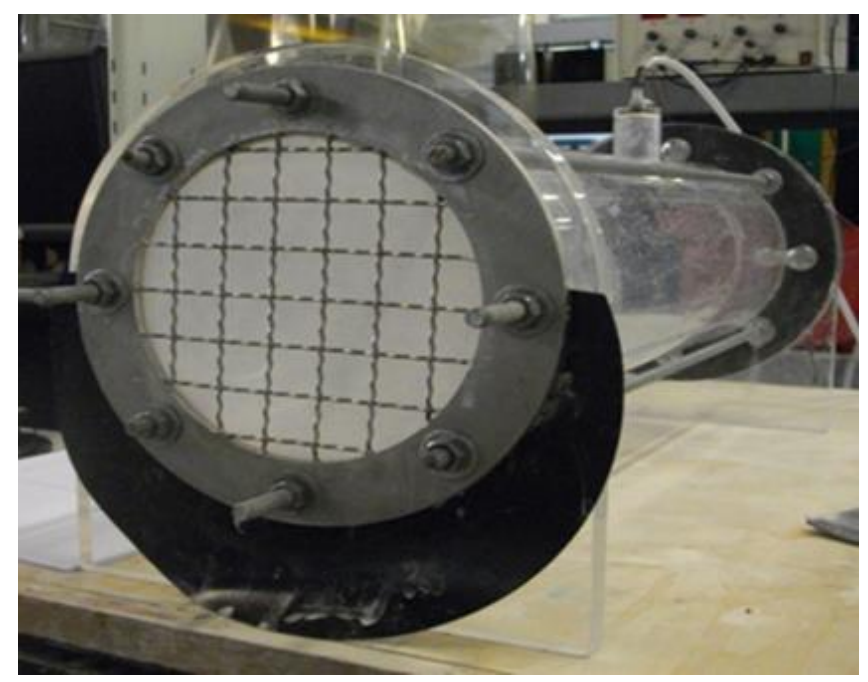

792 Figure 4. View of test cell before filling by sludge. 


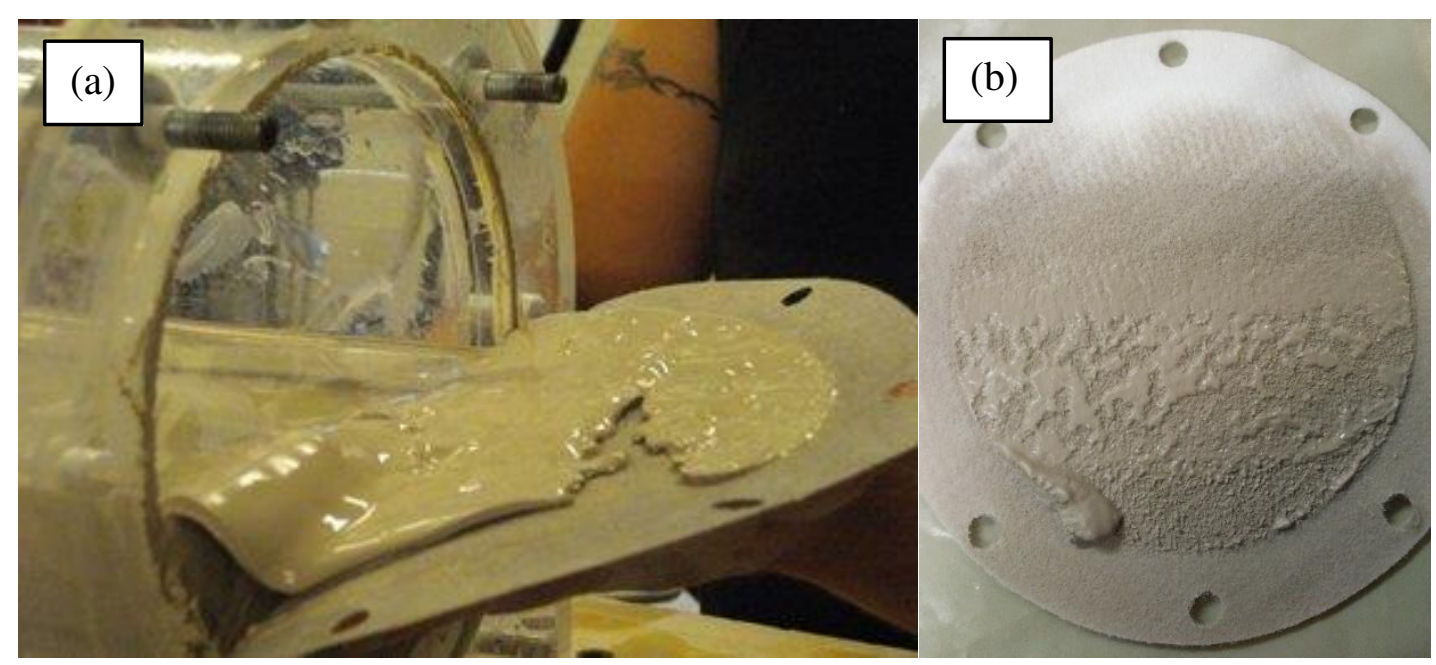

799 Figure 5. (a) View of typical filtration cell at end of test (NWTB-1, constant flow condition, 800 soil $\mathrm{A}$ at $200 \mathrm{~g} / \mathrm{L}$ ). (b) View of a filter geotextile at end of test (NWMB-2, constant flow 801 condition, soil B at $200 \mathrm{~g} / \mathrm{L})$.

802 

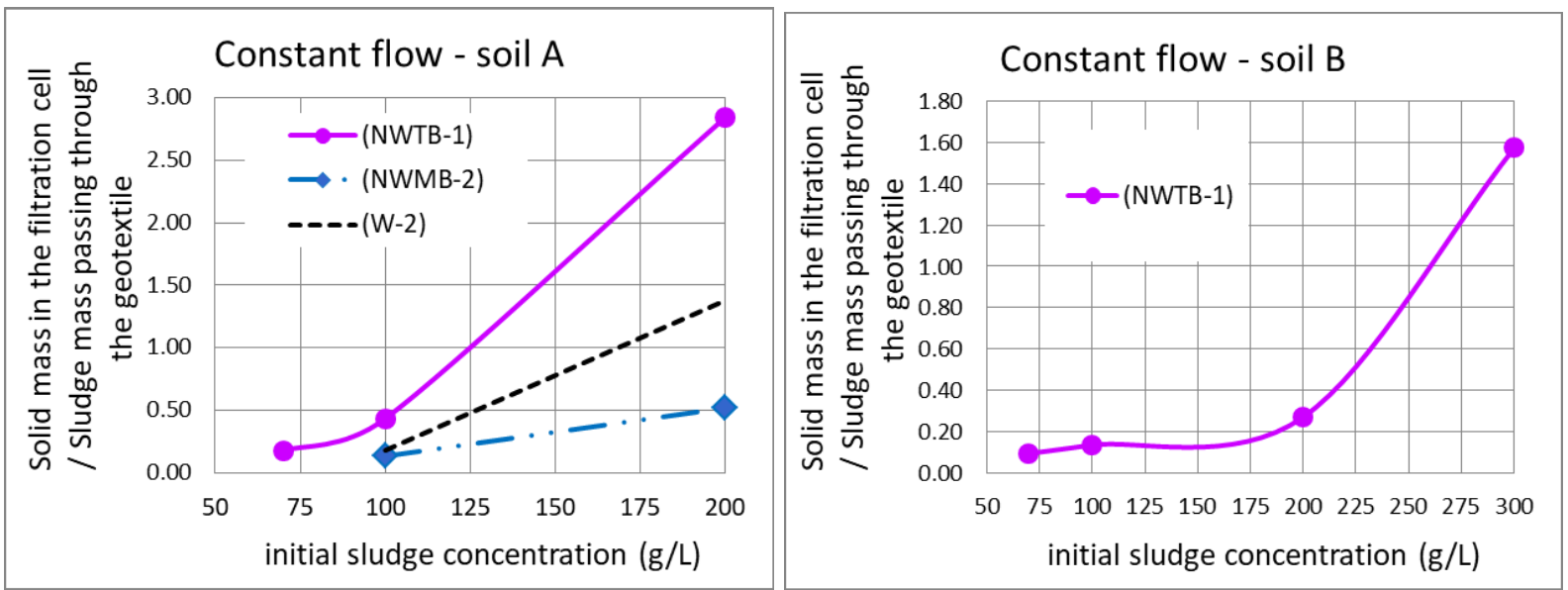

806 Figure 6. (a) Under constant-flow conditions and for soil A, ratio of solid mass retained in

807 filtration cell to sludge mass that passes through geotextile as a function of initial sludge

808 concentration and for several geotextile filters. (b) Same as panel (a) but for soil B and for the 809 single geotextile filter. Both panels refer to phase where the filtration is controlled by the 810 geotextile. 

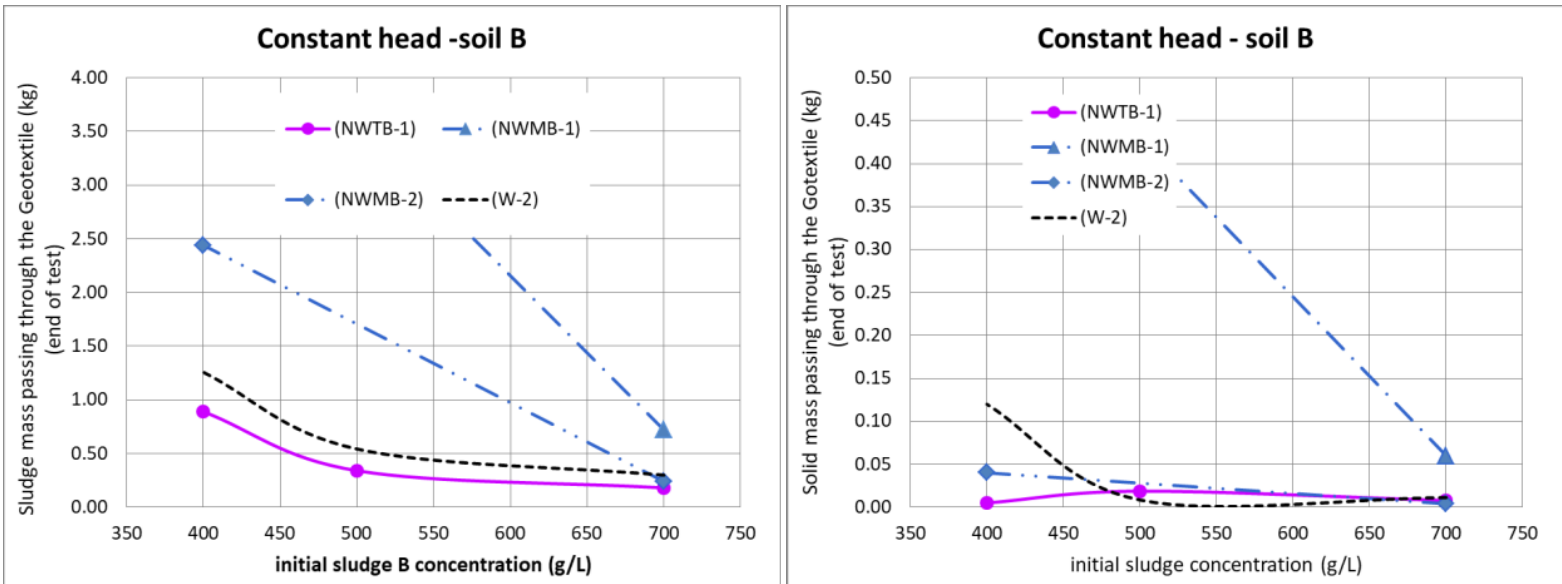

813 (left) Sludge mass passing through the geotextile measured at the end of the test

814 (right) Solid (fines) mass passing through the geotextile measured at the end of the test

816 Figure 7. (a) Sludge mass that has passed through the filter by end of test as a function of

817 initial sludge concentration for four geotextile filters. Soil B was used for these tests, which

818 were done under constant-head conditions. (b) Same as panel (a) but for solid mass instead of

819 sludge mass. Both panels refer to phase where the filtration is controlled by the geotextile. 

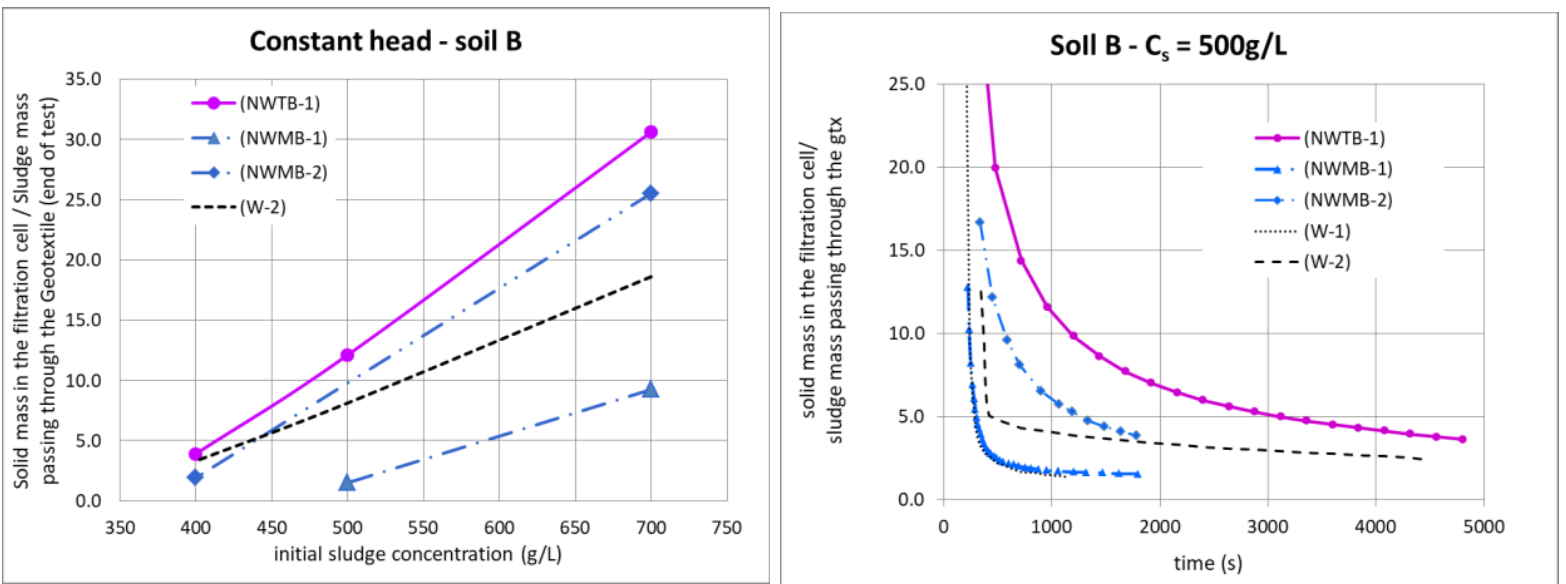

826 Figure 8. (a) Ratio of solid mass in filtration cell to sludge mass that passes through geotextile

827 filter during test as a function of initial sludge concentration and for four geotextile filters.

828 Tests were done under constant-head conditions, used soil B and filtration was controlled by

829 the geotextile. (b) Same ratio as in panel (a) shown as a function of time from onset of

830 filtration. Concentration of fines was $C_{\mathrm{s}}=500 \mathrm{~g} / \mathrm{L}$ and filtration was controlled by filter cake. 

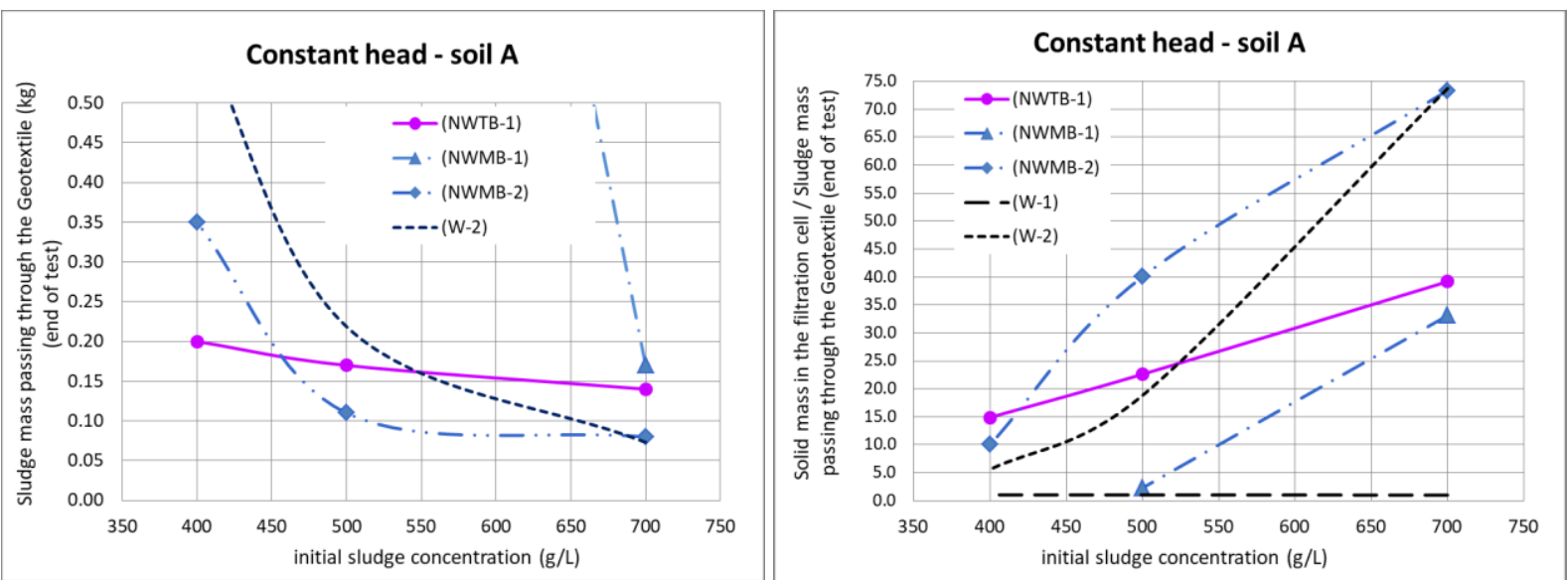

833 Figure 9. (a) Solid mass that passes through geotextile filter during test as a function of initial

834 sludge concentration and for four geotextiles. (b) Ratio of solid mass in the filtration cell to

835 sludge mass that passes through the geotextile filter during test as a function of initial sludge

836 concentration and for five geotextiles. For both panels (a) and (b), tests were done under

837 constant-head conditions, used soil A and filtration was controlled by the geotextile.

838

839

840 


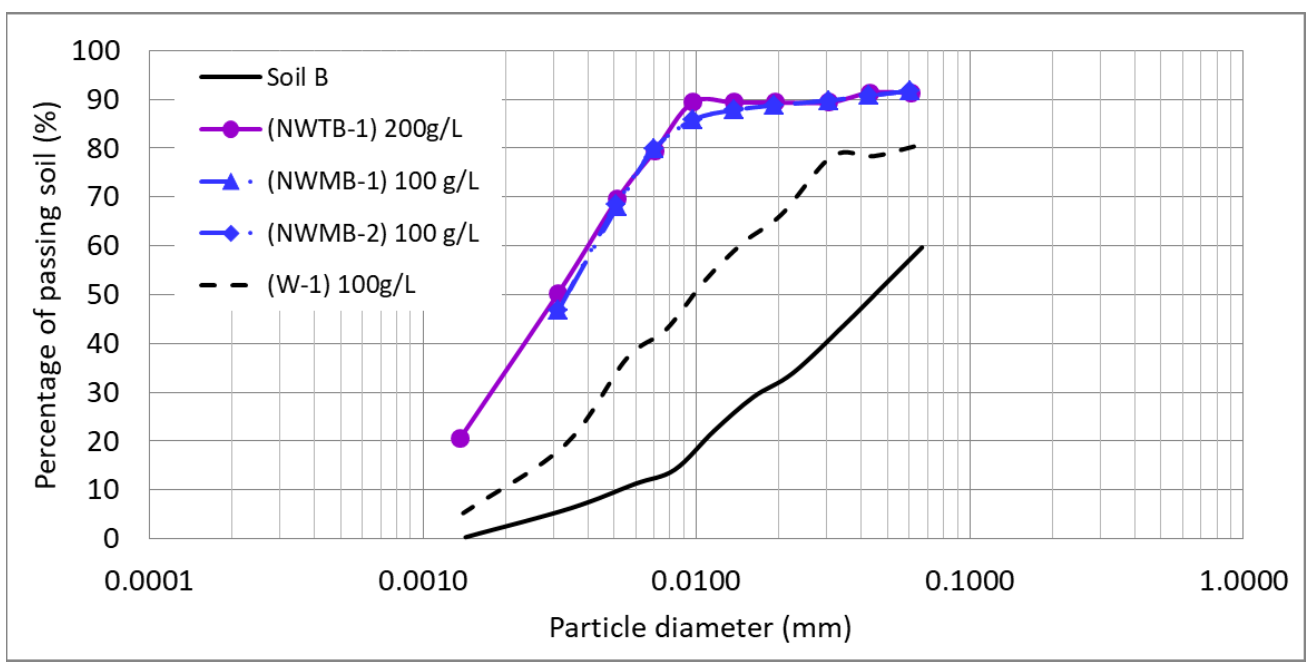

843 Figure 10. Particle-size distribution shown as fraction of particles that pass through filter as a

844 function of particle diameter under constant-flow conditions and for soil B. Filtration was 845 controlled by the geotextile.

846

847 

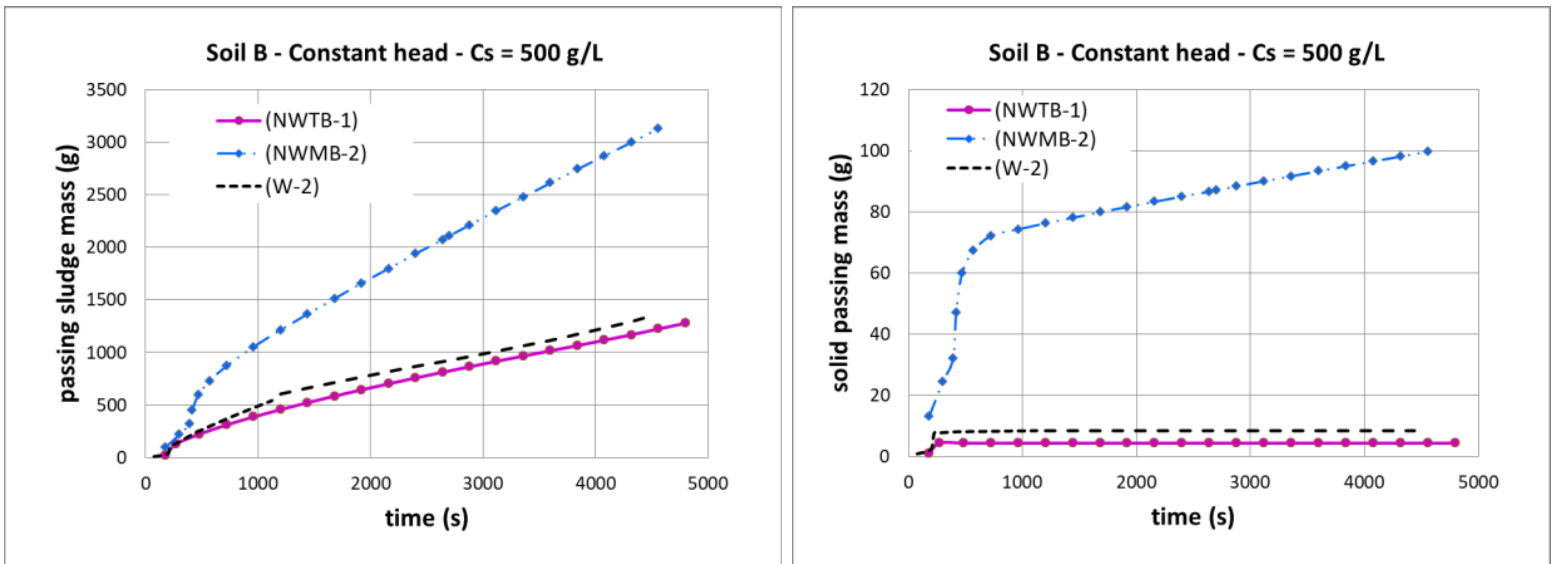

850 Figure 11. (a) Sludge mass that passes through the geotextile filter as a function of time from 851 onset of filtration and for three geotextiles. Tests were done under constant-head conditions, 852 with a fines concentration of $500 \mathrm{~g} / \mathrm{L}$, soil B and filtration controlled by the filter cake. (b) 853 Same as panel (a) but for solid mass instead of sludge mass. 


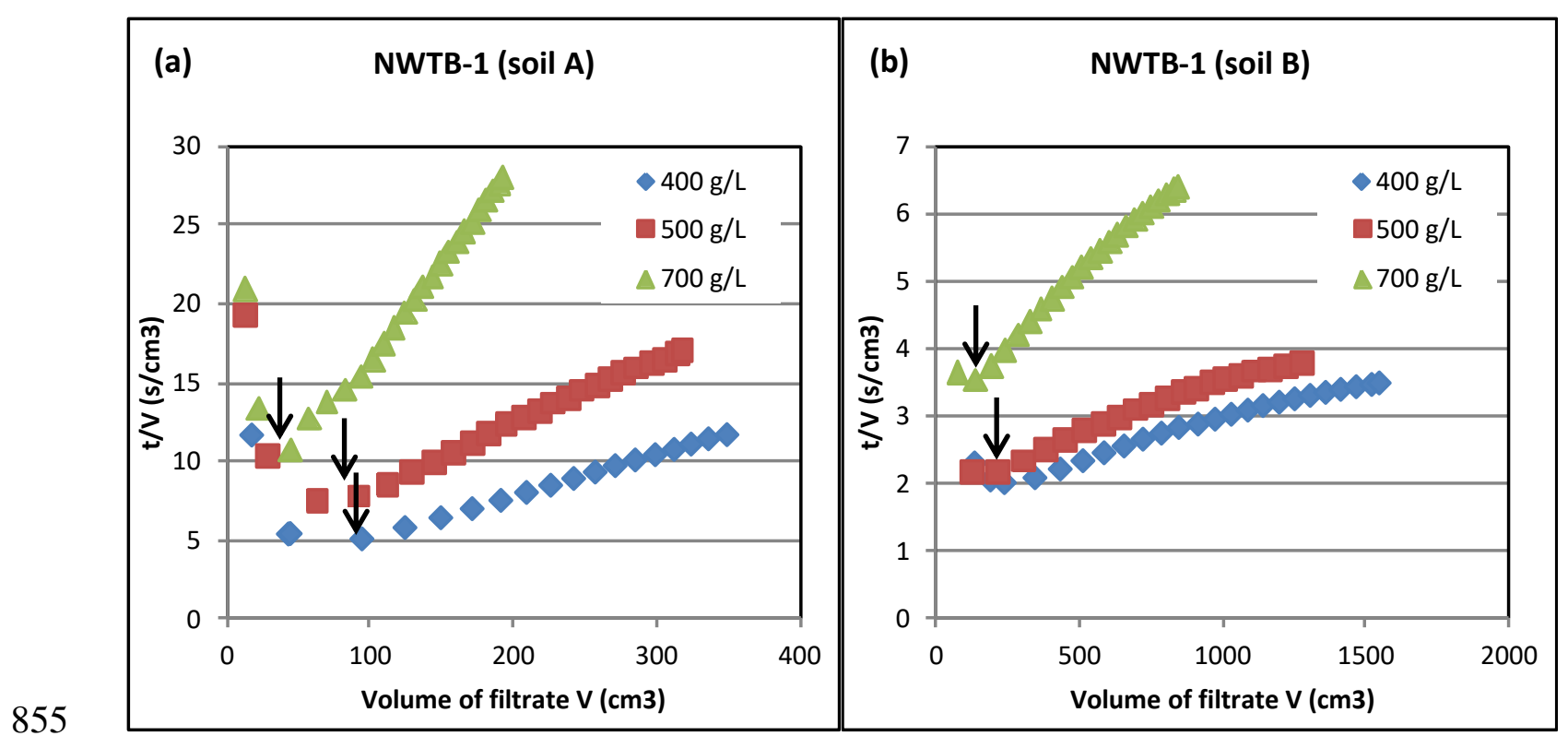

(c) various geotextiles (soil B, Cs=500g/L)

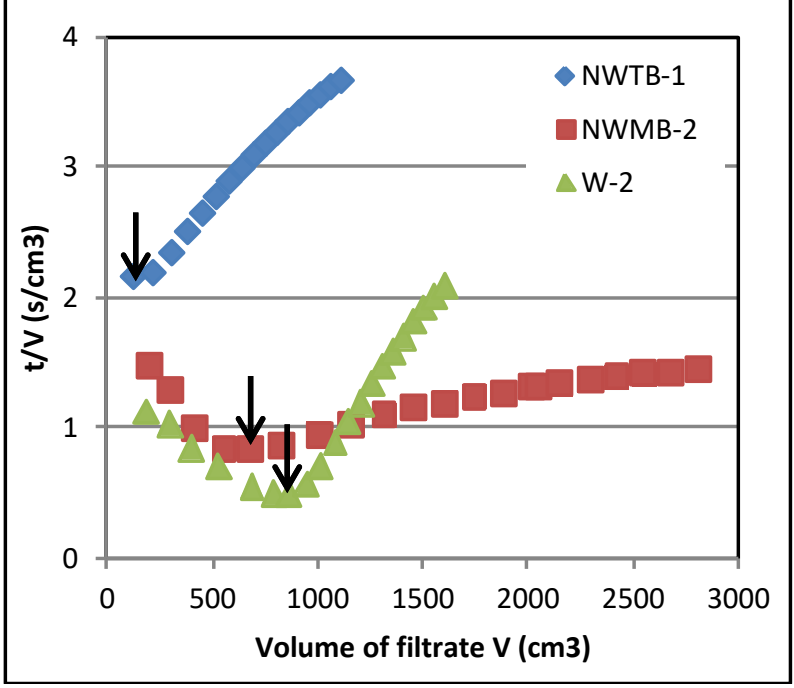

858 Figure 12. Inverse of time-averaged filtration rate as a function of the volume of filtrate for

859 geotextile filter NWTB-1 and several concentrations of fines for (a) soil A and (b) soil B. (c)

860 Same as panel (b) but for a concentration of fines of $C_{\mathrm{s}}=500 \mathrm{~g} / \mathrm{L}$ and for various geotextile

861 filters.

862 
Table 1. Particle-size distribution for soils used in filtration tests.

\begin{tabular}{|c|c|c|c|c|c|}
\hline Soil & $\mathrm{d}_{10}(\mathrm{~mm})$ & $\mathrm{d}_{50}(\mathrm{~mm})$ & $\mathrm{d}_{60}(\mathrm{~mm})$ & $\mathrm{d}_{85}(\mathrm{~mm})$ & $\mathrm{CU}$ \\
\hline A & 0.0014 & 0.005 & 0.06 & 0.016 & 4.5 \\
\hline B & 0.0051 & 0.045 & 0.067 & 0.13 & 13 \\
\hline
\end{tabular}

865 
Table 2. Assumptions of flow and concentrations of solid fines used in tests.

\begin{tabular}{|c|c|c|c|c|}
\hline Sludge flow condition & \multicolumn{3}{|c|}{ Concentration of solid fines (g/L) } \\
\hline $\begin{array}{c}\text { Constant head } \\
(10 \mathrm{kPa})\end{array}$ & 400 & 500 & 700 & \\
\hline $\begin{array}{c}\text { Constant flow } \\
(0.5 \mathrm{~L} / \mathrm{min} .)\end{array}$ & 70 & 100 & 200 & 300 \\
\hline
\end{tabular}

867 
Table 3. Main physical and hydraulic characteristics of the various geotextiles tested.

869

\begin{tabular}{|c|c|c|c|c|}
\hline Geotextile & Structure & $\begin{array}{c}\mathrm{O}_{90}(\mu \mathrm{m}) \\
(\mathrm{EN} \mathrm{ISO} \mathrm{12956)})\end{array}$ & $\begin{array}{l}\text { Water capacity } \\
\text { normal to plane } \\
\quad(\mathrm{mm} / \mathrm{s}) \\
\text { (EN ISO 11058) }\end{array}$ & $\begin{array}{c}\text { Mass per } \\
\text { unit area }\left(\mathrm{g} / \mathrm{m}^{2}\right) \\
\text { (EN ISO 9864) }\end{array}$ \\
\hline NWTB-1 & \multirow{4}{*}{$\begin{array}{c}\text { Thermally bonded } \\
\text { nonwoven }\end{array}$} & $<50$ & 8 & 160 \\
\hline NWTB-2 & & $<50$ & 1 & 220 \\
\hline NWTB-3 & & 61 & 20 & 125 \\
\hline NWTB-4 & & 140 & 50 & 125 \\
\hline NWMB-1 & \multirow{2}{*}{$\begin{array}{c}\text { Needle punched } \\
\text { nonwoven }\end{array}$} & 91 & 105 & 190 \\
\hline NWMB-2 & & 54 & 14 & 800 \\
\hline W-1 & \multirow{2}{*}{ Woven } & 109 & 13 & 327 \\
\hline $\mathrm{W}-2 *$ & & 63 & 127 & \\
\hline
\end{tabular}

870

871

872 
Table 4. Soils tested with various geotextiles, hydraulic conditions and concentrations of fines.

\begin{tabular}{|c|c|c|c|c|c|c|c|}
\hline Hydraulic & \multicolumn{4}{|c|}{ Constant flow $(0.5 \mathrm{~L} / \mathrm{min})$} & \multicolumn{3}{|c|}{ Constant head $(10 \mathrm{kPa})$} \\
\hline $\begin{array}{l}\text { Concentration } \\
\text { of fines }(\mathrm{g} / \mathrm{L})\end{array}$ & 70 & 100 & 200 & 300 & 400 & 500 & 700 \\
\hline Geotextile & \multicolumn{7}{|c|}{ Soil tested } \\
\hline (NWTB-1) & A, B & A, B & A, B & B & A, B & A, B & A, B \\
\hline (NWTB-2) & A, B & A, B & & & & A, B & A, B \\
\hline (NWTB-3) & B & B & & & & B & B \\
\hline (NWTB-4) & B & B & & & & B & B \\
\hline (NWMB-1) & & A, B & A, B & & A, B & A, B & A, B \\
\hline (NWMB-2) & & A, B & A, B & B & A, B & A, B & A, B \\
\hline$(\mathrm{W}-1)$ & & A, B & A, B & & A, B & A, B & A, B \\
\hline$(\mathrm{W}-2)$ & B & A, B & A, B & B & A, B & A, B & A, B \\
\hline
\end{tabular}


876 Table 5. For constant-flow conditions, system efficiency is given in terms of percent of

877 cumulated mass sludge that passes through the filter per theoretical cumulated mass of same.

878 "cnf" and "cfnst" indicates respectively "cell not filled" and "cell filled but filter not

879 stabilised".

\begin{tabular}{|c|c|c|c|c|c|c|c|}
\hline Soil & \multicolumn{3}{|c|}{ Soil A } & \multicolumn{4}{|c|}{ Soil B } \\
\hline $\begin{array}{l}\text { Concentration } \\
\text { of fines }(\mathrm{g} / \mathrm{L})\end{array}$ & 70 & 100 & 200 & 70 & 100 & 200 & 300 \\
\hline NWTB-1 & $12 \%$ & $11 \%$ & $3 \%$ & cnf & $\mathrm{cnf}$ & $40 \%$ & $13 \%$ \\
\hline NWTB-2 & $16 \%$ & $7 \%$ & & cnf & $\mathrm{cnf}$ & & \\
\hline NWTB-3 & & & & $\mathrm{cnf}$ & $\mathrm{cnf}$ & & \\
\hline NWTB-4 & & & & $\mathrm{cnf}$ & $\mathrm{cnf}$ & & \\
\hline NWMB-1 & & $\mathrm{cnf}$ & $\mathrm{cnf}$ & & $\mathrm{cnf}$ & cnf & \\
\hline NWMB-2 & & $22 \%$ & $21 \%$ & & $\mathrm{cnf}$ & $\mathrm{cnf}$ & $\mathrm{cnf}$ \\
\hline $\mathrm{W}-1$ & & $\mathrm{cnf}$ & cnf & & $\mathrm{cnf}$ & $\mathrm{cnf}$ & \\
\hline $\mathrm{W}-2$ & & $35 \%$ & $8 \%$ & & $\mathrm{cnf}$ & $\mathrm{cnf}$ & cfnst \\
\hline
\end{tabular}

880 
881 Table 6. For constant-head conditions, level of stabilization of the system observed in the first

882 set of tests as determined by the evolution in time of the mass of sludge that passes through

883 the filter and/or the mass of fines that passes through the filter. "S" indicates a stabilised

884 system (i.e., fines are blocked by filter after a certain time), and "U-S" indicates an

885 unstabilised system (i.e., fines continue to pass through filter over time).

886 Part 1: Tests were stopped based upon visual observation that fines were blocked by filter.

\begin{tabular}{|c|c|c|c|c|c|c|}
\hline Soil & \multicolumn{3}{|c|}{ Soil A } & \multicolumn{3}{|c|}{ Soil B } \\
\hline $\begin{array}{l}\text { Concentration } \\
\text { of fines }(g / L)\end{array}$ & 400 & 500 & 700 & 400 & 500 & 700 \\
\hline NWTB-1 & $\mathrm{S}$ & S & S & $\mathrm{S}$ & $\mathrm{S}$ & $\mathrm{S}$ \\
\hline NWTB-2 & & S & S & & $\mathrm{S}$ & \\
\hline NWTB-3 & & & & & $\mathrm{cnf}$ & U-S \\
\hline NWTB-4 & & & & & U-S & U-S \\
\hline NWMB-1 & U-S & $\mathrm{S}$ & $\mathrm{S}$ & U-S & U-S & $S$ \\
\hline NWMB-2 & $\mathrm{S}$ & $\mathrm{S}$ & S & U-S & U-S & $\mathrm{S}$ \\
\hline W-1 & $\mathrm{S}$ & $\mathrm{S}$ & $\mathrm{S}$ & U-S & U-S & U-S \\
\hline W-2 & $\mathrm{S}$ & $\mathrm{S}$ & $\mathrm{S}$ & $\mathrm{S}$ & $\mathrm{S}$ & $\mathrm{S}$ \\
\hline
\end{tabular}

Part 2: Same tests as in part 1 above, but tests ran for 90 minutes.

\begin{tabular}{|c|c|c|c|c|}
\hline Soil & \multicolumn{3}{|c|}{ Soil tested } \\
\hline $\begin{array}{c}\text { Concentration } \\
\text { of fines (g/L) }\end{array}$ & 300 & 400 & 500 & 700 \\
\hline NWTB-1 & B* & A, B & A, B \\
\hline NWMB-2 & & & \\
\hline
\end{tabular}


890 Table 7. Dependence of theoretical hindered settling $S_{\mathrm{h}}$ during the "transit time" on the

891 theoretical particle diameter $D_{\mathrm{h}}$ and on the sludge concentration $C_{\mathrm{s}}$, for soils A and B.

892

\begin{tabular}{|c|c|c|c|c|}
\hline$S_{\mathrm{h}}(\mathrm{mm})$ & $C_{\mathrm{s}}=70 \mathrm{~g} / \mathrm{L}$ & $C_{\mathrm{s}}=100 \mathrm{~g} / \mathrm{L}$ & $C_{\mathrm{s}}=200 \mathrm{~g} / \mathrm{L}$ & $C_{\mathrm{s}}=300 \mathrm{~g} / \mathrm{L}$ \\
\hline$D_{\mathrm{h}}(10 \mu \mathrm{m})$ & 86 & 82 & 71 & 61 \\
\hline$D_{\mathrm{h}}(20 \mu \mathrm{m})$ & $>300$ & $>300$ & $>250$ & $>200$ \\
\hline
\end{tabular}


893 Table 8. Under constant-head conditions and for soil B, table gives average sludge mass and 894 average solid mass that passes through the geotextile filter after cell is filled. (a) Comparison 895 of different geotextiles for a given solid concentration of fines in the sludge $\left(C_{\mathrm{s}}=500 \mathrm{~g} / \mathrm{L}\right)$

896 and (b) comparison of solid concentration of fines in the sludge for geotextile NWTB-1.

\begin{tabular}{|c|c|c|c|}
\hline Soil B $\left(C_{\mathrm{s}}=500 \mathrm{~g} / \mathrm{L}\right)$ & $\begin{array}{c}\text { Average sludge mass } \\
\text { passing through } \\
\text { geotextile }(\mathrm{g} / \mathrm{min})\end{array}$ & $\begin{array}{c}\text { Average solid mass } \\
\text { passing through } \\
\text { geotextile }(\mathrm{g} / \mathrm{min})\end{array}$ & $\begin{array}{c}\text { Average mass of } \\
\text { water passing } \\
\text { through geotextile } \\
(\mathrm{g} / \mathrm{min})\end{array}$ \\
\hline NWTB-1 & 14.2 & 0.0 & 14.2 \\
\hline NWTB-2 & 20.0 & not measured & not measured \\
\hline NWTB-3 & 17.7 & not measured & not measured \\
\hline NWTB-4 & 87.0 & not measured & not measured \\
\hline NWMB-2 & 35.1 & 0.4 & 34.7 \\
\hline W-2 & 13.8 & 0.0 & 13.8 \\
\hline
\end{tabular}

\begin{tabular}{|c|c|c|c|}
\hline Soil B, NWTB-1 & $\begin{array}{c}\text { Average sludge mass } \\
\text { that passes through } \\
\text { geotextile }(\mathrm{g} / \mathrm{min})\end{array}$ & $\begin{array}{c}\text { Average solid mass } \\
\text { that passes through } \\
\text { geotextile }(\mathrm{g} / \mathrm{min})\end{array}$ & $\begin{array}{c}\text { Average mass of } \\
\text { water that passes } \\
\text { through geotextile } \\
(\mathrm{g} / \mathrm{min})\end{array}$ \\
\hline$C_{\mathrm{s}}=400 \mathrm{~g} / \mathrm{L}$ & 15.4 & 0.0 & 15.4 \\
\hline$C_{\mathrm{s}}=500 \mathrm{~g} / \mathrm{L}$ & 14.2 & 0.0 & 14.2 \\
\hline$C_{\mathrm{s}}=700 \mathrm{~g} / \mathrm{L}$ & 8.4 & 0.0 & 8.4 \\
\hline
\end{tabular}


Table 9. Same as Table 8(b) but for soil A and geotextile NWTB -1.

\begin{tabular}{|c|c|c|c|}
\hline Soil A, NWTB-1 & $\begin{array}{c}\text { Average sludge mass } \\
\text { that passes through } \\
\text { geotextile }(\mathrm{g} / \mathrm{min})\end{array}$ & $\begin{array}{c}\text { Average solid mass } \\
\text { that passes through } \\
\text { geotextile }(\mathrm{g} / \mathrm{min})\end{array}$ & $\begin{array}{c}\text { Average mass of } \\
\text { water that passes } \\
\text { through geotextile } \\
(\mathrm{g} / \mathrm{min})\end{array}$ \\
\hline$C_{\mathrm{s}}=400 \mathrm{~g} / \mathrm{L}$ & 3.9 & 0.0 & 3.9 \\
\hline$C_{\mathrm{s}}=500 \mathrm{~g} / \mathrm{L}$ & 2.9 & 0.0 & 2.9 \\
\hline$C_{\mathrm{s}}=700 \mathrm{~g} / \mathrm{L}$ & 1.7 & 0.0 & 1.7 \\
\hline
\end{tabular}

899

900 
901 Table 10. Specific cake resistance $\alpha$ measured in second series of tests, which ran for 90 902 minutes.

\begin{tabular}{|c|c|c|c|}
\hline \multicolumn{4}{|c|}{ Specific cake resistance $\alpha(\mathrm{m} / \mathrm{kg})$} \\
\hline $\begin{array}{l}\text { Concentration of } \\
\text { fines }(\mathrm{g} / \mathrm{L})\end{array}$ & 400 & 500 & 700 \\
\hline \multicolumn{4}{|c|}{ Soil A } \\
\hline NWTB-1 & $4.7 \times 10^{11}$ & $5.6 \times 10^{11}$ & $1.1 \times 10^{12}$ \\
\hline \multicolumn{4}{|c|}{ Soil B } \\
\hline NWTB-1 & $1.6 \times 10^{10}$ & $1.7 \times 10^{10}$ & $3.6 \times 10^{10}$ \\
\hline NWMB-2 & & $8.8 \times 10^{8 * *}$ & \\
\hline $\mathrm{W}-2$ & & $2.8 \times 10^{10}$ & \\
\hline
\end{tabular}

903

904 